\title{
副腎皮質の過形成および腫瘍組織の器官培養
}

\author{
慶応義熟大学医学部泌尿器科学教室 村 并勝
(主任: 大越正秋教授)
}

\section{ADRENOCORTICAL HYPERPLASIAS AND TUMORS IN ORGAN CULTURE}

\author{
Masaru Murai \\ Department of Urology, School of Medicine, Keio University, Tokyo
}

(Director: Prof. M. Ohkoshi)

Adrenocortical hyperplasias experimentally produced in rats were placed in organ cultcue and studied as well as human adrenals from 16 surgical materials ( 5 controls; 11 hyperfunctioning human adrenocortinal tissues including 3 adenomas and each 2 hyperplasias from Cushing's syndrome and primany aldosteronism and 1 adenoma from adrenogenital syndrome) and the following results were obtained.

1. Adrenocortical hyperplasia by aniline injections was demonstrated in female rats (weight of adrenals $26.0 \pm 10.9 \mathrm{mg}$ by 7 day treatment; $57.0 \pm 6.0 \mathrm{mg}$ in controls).

2. Hyperplastic rat adrenals were cultured with and without ACTH, and the histological findings were comparatively studied. Adrenal hyperplasias cultured 7 days preserved better morphology than untreated group. The best histological preservation was found in hyperplasia cultured with 0.2 $\mathrm{IU} / \mathrm{ml}$ of ACTH for 7 days.

3. Sixteen human materials were cultured for 48 hour to 7 days (14 days in part) and tolerated for electron microscopy as well as routine histology.

4. Normal human adrenocortical tissues maintained the basic structures of cytoplasmic organellae during the 7 day culture period. By ACTH $0.02 \mathrm{IU} / \mathrm{ml}$ in the culture media, mitochondria, smooth endoplasmic retuculi (SER) and vesicles were increasing while lipid granule decreased.

5. Adenoma cells from Cushing's syndrome maintained their basic structure with and without ACTH during the 7 day culture period. By ACTH $0.02 \mathrm{IU} / \mathrm{ml}$ in the media, a better preservation of the tissues was obtained in 14 day cultures, while they tended to be degenerated by ACTH $0.2 \mathrm{IU} / \mathrm{ml}$.

6. In hyperplasias from Cushing's syndrome, the cytoplasmic basic structures were well maintained by ACTH. The optimum concentration, $0.02 \mathrm{IU} / \mathrm{ml}$ of $\mathrm{ACTH}$, increased the size and number of mitochondria and SER.

7. Adenoma cells from primary aldosteronism included a characteristic myelin-like structure in cytoplasm as well as non-tumor part of the adrenal before and after culture. With ACTH in the media, mitochondria as well as vesicles were enlarged.

8. In hyperplasia from primary aldosteronism, ACTH in the media decreased the size of mitochondria, which looked thinner like threads and the cristae disappeared. Lipid granules were also decreased. The results indicate the factors affecting on hyperplasia of primary aldosteronism other than ACTH.

9. Adenoma cells from adrenogenital syndrome well maintained the original structures in 48 hour to 7 day cultures. By ACTH, at a concentration of $0.02 \mathrm{IU} / \mathrm{ml}$ in the media, mitochondria and lipid granules increased as well as abundant endoplasmic reticuli.

10. Characteristic myelin-like structures were seen in adenoma cells from primary aldosteronism treated with spironolactone. Similar lamellar structures were also recognized in hyperplasia of Cushing's syndrome and adenoma of adrenogenital syndrome.

11. The myelin-like structures changed the characteristic laminated configuration into fluidlike 
extension after culture with or without ACTH. This was more prominent in adenoma cells fiom adrenogenital syndrome, in which the laminated structure showed a closer relationship to SER and RER and the role of functional connection.

The above mentioned results partly disclosed the pathological physiology of adrenocortical hyperfunction, and the present research method was proved to be useful for further clnical investigation.

従来，比較的まれな疾患とされていた Cushing 症候 群, 原発性アルドステロン症, 副腎性器症候群など副腎 皮質機能六進に上る疾患は，薬理学的診断法の進歩や血 管撮影法の導入等により容易に発見されるようになつた ため,最近著しくその数を增し，本邦報告例は1,000例を 越克ようとしている。これに伴つて手術的に摘出した副 腎の腫瘍扰上び過形成組織の形態についても詳細に研究 されるようになり電子顕微鏡的観察を含め，すでに数多

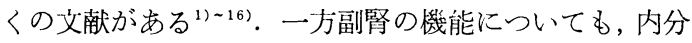
泌学的, 生化学的な究明が着々と行なわれつつあるが， 依然機能と形態の間には多くの未解決点が残されてい る、著者はヒト副腎皮質過形成あるいは腫瘍の組織培養 は本邦はもとより外国にもまだ報告がないことに着目 乙器官培養法の導入により，副腎皮質組織の形態と機能 の関連を追求しょうと試みた．本研究はまずラット副腎 皮質に実験的過形成を作り，その組織の器官培養を行な い，培養条件を設定し，同時に培養液に添加した ATCH の影響を観察，つぎにこれに基づき手術により摘出した 副腎皮質機能元進患者の組織を器官培養し，ACTHの影 響を光顕的, 超微形態学的に観察し, 数多くの興味ある 結果を得たので報告する.

\section{基礎研究}

1. 研究材料拈よび方法

1）実験的副腎皮質過形成

1970年ラットに実験的副腎過形成を作ることに成功し た Kovacs et al ${ }^{17)}$ の方法に従つた。すなおち，Wistar 系成熟雌性ラット（平均体重 $160 \mathrm{~g}$ ) 15匹を 5 匹ずつ 3 群に分け, 第 1 群は無処置対照群とし, 第 2 , 第 3 群に は30mg aniline (Kanto chemical Co. Tokyo) 加 corn oil $0.2 \mathrm{ml}$ を 1 日 1 回皮下注射した。第 2 群には 7 日 間，第3群には14 日間 aniline をとれぞれ投与し，8 日，および15日目にェーテル麻酔下に副腎皮質組織を無 菌的に摘出，器官培養を行なつた。

2）器官培養法

Tazaki et $\mathrm{al}^{18)}$, 尾関 ${ }^{19}$ らが膀胱腫瘍組織について行 なつた器官培養法に準じた。すなわち無菌的に摘出した 材料を, 約 $2 \mathrm{~mm}$ の長さの立方体に細断し，この組織片を 直径 $3 \mathrm{~cm}$ の小型蓋付シャーレに入れた gelfoam sponge
(Upjhon) の上に載せる. 培養液として, Eagle's MEM （千葉血清）に $15 \%$ 仔牛血清（千葉血清）を加えたもの を使用した，培養液の $\mathrm{pH}$ は 7.2〜 7.4亿調整した。感染 防止のため penicillin 10Cunit/dl streptomycin $100 \mathrm{mg} / \mathrm{dl}$ を加えて使用した。

培養液の交换は原則として48時間每に行ない，2 日か ら14日間まで培鉒を行なつた，培養シャーレはガラス製 の chamber に收容し $95 \%$ 空気，5\%炭酸ガスの混合の 気相で 2 気月， $37^{\circ} \mathrm{C}$ に保つた。培琴は 3 群に分け，第 1 群は対照群として, 第 2 矿の培餘液には合成 ACTH (Cortrosyn, N.V. Organon, Holland) $0.02 \mathrm{IU} / \mathrm{ml}$ 加光, 第 3 群の培差液には ACTH $0.2 \mathrm{IU} / \mathrm{ml}$ を加えた。

3) 組織学的観察

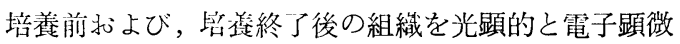
鏡的に観察した。光顕標本は $10 \%$ formalin に固定し， 通常の paraffin 包埋し, Minot 型 microtome によつて 連続切片とし，H-E その他の染色を行なつた．電子顕 微鏡的観察は $1 \%$ オスミウム酸固定，脱水後 Luft 法に したがつて Epon 樹脂に包埋, LKB 型ミクロトームに より超溥切片として, 日占電子顕微鏡 HS7S 型にて, 超 微細構造を観察した。

2. 研究結果

ラットに対する aniline の投与による体重および副腎 重量の変化は表 1 のとおりである. aniline 非投与の無 処置群の平均副腎重量は57.0土6.0mgであつた。 aniline 7 日間投与群の平均副腎重量は $260 \pm 10.9 \mathrm{mg}$ であり，14 月間投与群では平均副掔佢量が $270 \pm 10.5 \mathrm{mg}$ であつた。 推計学的梌定により aniline 投与群の副腎重量増加は, 無処置対照群に比較して有意差を認めた（伦険率 $5 \%$ 検 定).

Anlline 7 日間投与群と，14日間投与群の間には有意 差はなかつた。

肉腿的には肥大し兏白質となり，割面では皮質の厚み は明らかに増している(図 1)，組織学的には aniline 投与群では, 無処蹎群（図2）に比較して，皮質が著明 に厚みを増し，その典型的な層構造は不明瞭となり，と くにZ. glomerulosa の細胞は汪とんど消失したと見兄る 
Table 1. Adrenocortical hyperplasia induced in rats by aniline

\begin{tabular}{|c|c|c|c|c|c|}
\hline no. & group & $\begin{array}{c}\text { duration } \\
\text { of } \\
\text { treat- } \\
\text { ment }\end{array}$ & $\begin{array}{c}\text { final } \\
\text { body } \\
\text { weight } \\
(\mathrm{g})\end{array}$ & $\begin{array}{c}\text { adrenal } \\
\text { weight } \\
(\mathrm{mg})\end{array}$ & mean土s.e. \\
\hline 1 & \multirow{5}{*}{ control } & & 170 & 50 & \multirow{5}{*}{$57.0 \pm 6.0$} \\
\hline 2 & & & 180 & 60 & \\
\hline 3 & & & 180 & 50 & \\
\hline 4 & & & 185 & 65 & \\
\hline 5 & & & 190 & 60 & \\
\hline 6 & \multirow{5}{*}{ aniline } & \multirow{5}{*}{7 days } & 150 & 250 & \multirow{5}{*}{$260.0 \pm 10.9$} \\
\hline 7 & & & 185 & 260 & \\
\hline 8 & & & 175 & 280 & \\
\hline 9 & & & 160 & 250 & \\
\hline 10 & & & 160 & 260 & \\
\hline 11 & \multirow{5}{*}{ aniline } & \multirow{5}{*}{14 days } & 187 & 255 & \multirow{5}{*}{$266.0 \pm 10.5$} \\
\hline 12 & & & 195 & 260 & \\
\hline 13 & & & 198 & 280 & \\
\hline 14 & & & 180 & 275 & \\
\hline 15 & & & 175 & 280 & \\
\hline
\end{tabular}

ものもあつた. したがつて皮質の大部分は Z. fasciculata 型の大型の多角形の細胞によつて占められる結果となつ ていた.

大部分の皮質細胞は膨化し，好酸性顆粒を含さ泡沫状 の胞体を有するものが多いが，一部では脂肪球が細胞質 をみたし核の扁在している細胞もみられる。また一部に は細胞の変性壞死もみられる，核は一般に小型円型で染 色質に富み karyorrhexis がところどころにみられる.

これらの変化は 7 日間投与群（図 3 ）より14日間投与群 （図 4）において，より著明であつた.

器官培養に拈いては，2 日間培養と7日間培養とを比 較すると，その組織学的所見はほぼ同様の傾向を示した が, 変性壊死の傾向は後者の方がより著明であつた.

Aniline 無処潐群の器官培養では, ACTH 非添加群は 皮質表層が一部維持されているが，内層はほとんど壊死 に陷つている（図 5 ). ACTH 添加群は皮質表層はほと んど正常に保たれているが，内層の細胞は細胞境界がは つきりせず胞体は淡明化し核は融解像を示すものがある (図6,図 7 )。これらの変化は ACTH $0.2 \mathrm{IU} / \mathrm{ml}$ 添加 群に強く, 細胞保存は ACTH $0.02 \mathrm{IU} / \mathrm{ml}$ 添加群か良 好であつた。

Aniline 投与群の器官培差では, ACTH 非添加培養組 織で，皮質細胞は平均して良好に維持されている. 細胞 が大きく淡明で，配列の乱れはないが，核の大小不同が
めだち，ところどころ karyrrohexis も認められた（図 8). ACTH 添加群は胞体は大型多角形, 配列の乱れが あるが全体に胞体好酸性が強く，核は円形ないし楕円形 で多少の大小不同はあるが，変形はなく，核小体が明瞭 のものが多い.これら所見は ACTH $0.2 \mathrm{IU} / \mathrm{ml}$ 添加群 に著明で ACTH $0.02 \mathrm{IU} / \mathrm{ml}$ 添加群では一部に変性を認 め, 過形成組織の維持には ACTH $0.2 \mathrm{IU} / \mathrm{ml}$ の方が $0.02 \mathrm{IU} / \mathrm{ml}$ より良好であつた（図 $9,10 ）$.

3. 小括

ラットに実験的副腎皮質過形成をつくり, 摘出後器官 培養を行なつて 7 日間 in vitro に維持が可能であつた。 また培養液に ACTH を添加することにより培養組織の 保存状態は良好となつた。正常組織には ACTH 0.02 $\mathrm{IU} / \mathrm{ml}$ の添加が適し，過形成組織には ACTH $0.2 \mathrm{IU} / \mathrm{ml}$ が適していることが判明した。

\section{臨床例による研究}

\section{1. 研究材料および方法}

昭和46年 1 月より昭和 48 年 2 月までの間に，慶応義塾 大学病院とその関連病院において手術を受け摘出された 材料を本研究に用いた11例の副腎皮質機能六進症症例は 表 2 に示す通りである. 臨床症状として Cushing 症候群 を示したもの 5 例，らち腺腫が 3 例，過形成 2 例，原発 性アルドステロン症を示したもの 5 例, 万ち腺腫 3 例, 過形成 2 例であつた. 副腎性器症候群は 1 例で病理組織 学的には腺腫であつた. 他に 2 例の腎腫瘍および 1 例の 腎孟腫瘍の根治的腎摘出術時に得られた副腎と，1例の 乳癌患者の副腎摘出組織および後腹膜腔の試験開腹時に 遇然得られた副腎組織 1 例の計 5 例を対照とした。

材料は摘出後ただちに $4{ }^{\circ} \mathrm{C}$ 塩類溶液 (Eagle's MEM) に入れ，無菌的に細切し60分以内に培養を開始した。

2 . 研究結果

1）光学顕微鏡所見

a）正常副腎皮質組織：被膜の直下ょり，Z. glomerulosa, Z. fasciculata, Z. reticularis に区別されるが， 実際はその境界は明瞭でない例が多い。細胞は多角形な いし円柱状, 核は円形小型で 3 層とも類似するが, 胞体 の明るい, いわゆる clear cell と eosin 好性の compact cell に区別すると, 正常副腎皮質では表層の $2 / 3$ は前者 が多く, 内層 ${ }^{1} / 3$ は後者が多い. しかし両者が中 $1 / 3$ 部に 全く混在している例もある. 培差 2 日間ではお括むね正 常構造が維持されていた.

b) Cushing 症候群

i ) 腺腫 : compact cell と clear cell の割合は大体 
Table 2 Cases of adrenocortical hyperplasia and tumor

\begin{tabular}{|c|c|c|c|c|c|c|c|c|}
\hline case & name & age & $\operatorname{sex}$ & clinical Dx. & pathological Dx. & side & size $(\mathrm{cm})$ & wt. (g) \\
\hline 1 & A. N. & 25 & $\mathrm{~F}$ & $\begin{array}{l}\text { Cushing's } \\
\text { syndrome }\end{array}$ & adenoma & lt & $3.5 \times 2.5 \times 2.0$ & 15.0 \\
\hline 2 & T. S. & 19 & $\mathbf{M}$ & $\begin{array}{l}\text { Cushing's } \\
\text { syndrome }\end{array}$ & adenoma & lt & $3.0 \times 2.5 \times 2.5$ & 13.0 \\
\hline 3 & S. S. & 25 & $\mathrm{~F}$ & $\begin{array}{l}\text { Cushing's } \\
\text { syndrome }\end{array}$ & adenoma & lt & $2.8 \times 3.3 \times 2.0$ & 7.0 \\
\hline 4 & H. M. * & 41 & F & $\begin{array}{l}\text { Cushing's } \\
\text { syndrome }\end{array}$ & $\begin{array}{l}\text { nodular } \\
\text { hyperplasia }\end{array}$ & $\mathrm{rt}$ & $7.5 \times 2.0 \times 0.9$ & 10.0 \\
\hline 5 & M. O. $* *$ & 32 & $\mathrm{~F}$ & $\begin{array}{l}\text { Cushing's } \\
\text { syndrome }\end{array}$ & $\begin{array}{l}\text { diffuse } \\
\text { hyperplasia }\end{array}$ & rt & $7.7 \times 2.0 \times 1.2$ & 8.5 \\
\hline 6 & S. T. & 38 & $\mathrm{~F}$ & $\begin{array}{l}\text { primary } \\
\text { aldosteronism }\end{array}$ & adenoma & lt & $1.5 \times 1.2 \times 1.0$ & 1.2 \\
\hline 7 & N. N. & 40 & $\mathrm{~F}$ & $\begin{array}{l}\text { primary } \\
\text { aldosteronism }\end{array}$ & adenoma & $\mathrm{rt}$ & $1.2 \times 1.3 \times 1.5$ & 1.1 \\
\hline 8 & M. E. $* * *$ & 23 & F & $\begin{array}{l}\text { primary } \\
\text { aldosteronism }\end{array}$ & adenoma & $\mathrm{rt}$ & $2.5 \times 2.2 \times 1.8$ & 9.0 \\
\hline 9 & Y. K. & 42 & $\mathbf{M}$ & $\begin{array}{l}\text { primary } \\
\text { aldosteronism }\end{array}$ & $\begin{array}{l}\text { nodular } \\
\text { hyperylasia }\end{array}$ & $\mathrm{rt}$ & $7.0 \times 1.5 \times 1.8$ & 6.3 \\
\hline 10 & N. Y. & 38 & F & $\begin{array}{l}\text { primary } \\
\text { aldosteronism }\end{array}$ & $\begin{array}{l}\text { nodular } \\
\text { hyperplasia }\end{array}$ & $\mathrm{rt}$ & $7.5 \times 1.2 \times 2.0$ & 7.5 \\
\hline 11 & H. I. & 28 & F & $\begin{array}{l}\text { adrenogenital } \\
\text { syndrome }\end{array}$ & adenoma & lt & $4.2 \times 2.5 \times 2.5$ & 17.0 \\
\hline
\end{tabular}

* the other side operated 4 years ago

** the other side operated 2 years ago

*** the other side operated 2 years ago

同じ程度で，図11に示したように混在している所が多 い. compact cell の部分を強桩大でみると図 12 のごと く eosin に濃染する顆粒が豊富である.

ACTH 非添加群の 2 日間培養では図 13 のごとく変化 が著しく, ACTH 0.02IU/ml の添加群でも同様に变性 が強い（図14）。しかし ACTH $0.2 \mathrm{IU} / \mathrm{ml}$ でも変性は見 られるが，他の群に比較して保存は良好である（図15）。

ii）過形成: Z. fasciculata の細胞に似たいわゆる clear cell が䒽状に配列，この中に compact cell が混 在している（図16）。混合部を強拆大でみると図17のご とく clear cell は肥大膨満し，少量の網状構造を持ち， compact cell は核が小さく圧迫されて存在する. 培盖 2 日後全体に細胞は萎縮を示すが (図18)，ACTH 0.02 $\mathrm{IU} / \mathrm{ml}$ 添加群では図19に示すごとく胞体内の eosin 好 性は増すが，細胞膜が不明瞭となつてくる。 ところが ACTH $0.2 \mathrm{IU} / \mathrm{ml}$ 添加群では図20のごとく，核も細胞膜 もよく保存され培養前の状態に最も近い像を示した。

c）原発性アルドステロン症

i ）腺腫：腫瘍細胞はほとんど均一な clear cell より なり，図21に示すごとく被膜は明瞭でないが，周辺の非 腫瘍部とははつきり区別でさる．強拡大でみると眯な間 質に囲まれた 5 ないし10個の細胞が sheet 状に配列して
いる(図22)，ACTH 非添加群では全体として萎縮傾向 を示すが (図23)，ACTH 0.02IU/ml 添加群では培養 前の状態がよく保存され，核の大小不同，網状構造をも つ胞体，明瞭な細胞膜も対照よりむしろ組織活性の上昇 を示唆した（図24）。

ii）過形成：結節性の過形成を示す例では，図25のご とく主として clear cell よりなる. 強払大では図26のご とく少量の線維性間質に囲まれた clear cell の集簇で, 核は円形で大きさは均一である，ACTH 非添加で培養 すると核，胞体ともに著しく萎縮する（図27）、ACTH $0.02 \mathrm{IU} / \mathrm{ml}$ 添加群でも核の萎縮 が著明で胞体もはなは だしく退縮していた（図28）。

d) 副腎性器症候群

i ）腺腫：腫瘍細胞は eosin 好性のいわゆる compact cell よりなる（図29）。核は円型で他の腫瘍と大差なく， 強拡大では細胞は小さく細顆粒状でときに円形の封入体 を認める（図30）. ACTH $0.02 \mathrm{IU} / \mathrm{ml}$ 添加により胞体は やや明るく変化した (図31)。ACTH $0.2 \mathrm{IU} / \mathrm{ml}$ の添加 により, 胞体はさらに明るくなり, 細胞はやや大きさを 増した。

2）電子顕微鏡的観察所見

a）正常副腎皮質組織 
Fig. 1. Aniline treated rat adrenal hyperplasia for 7 days culture and controls (upper) Cut surface of hyperplastic adrenal shows ivory-white

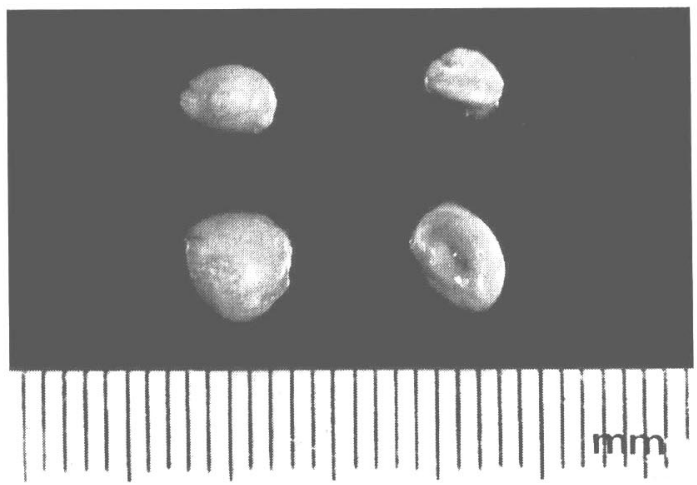

Fig. 3. 7 day aniline treated rat adrenal. Cellular enlargement with granulated cytoplasm.

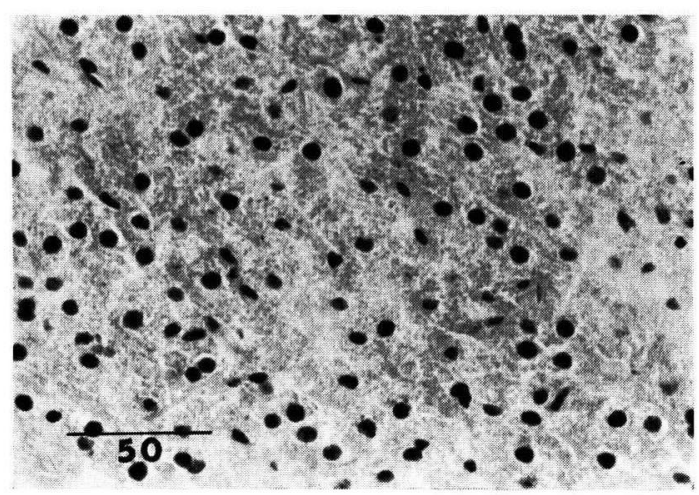

Fig. 5. Untreated rat adrenal 7 day organ culture without ACTH. Degenerated Z. fasciculata.

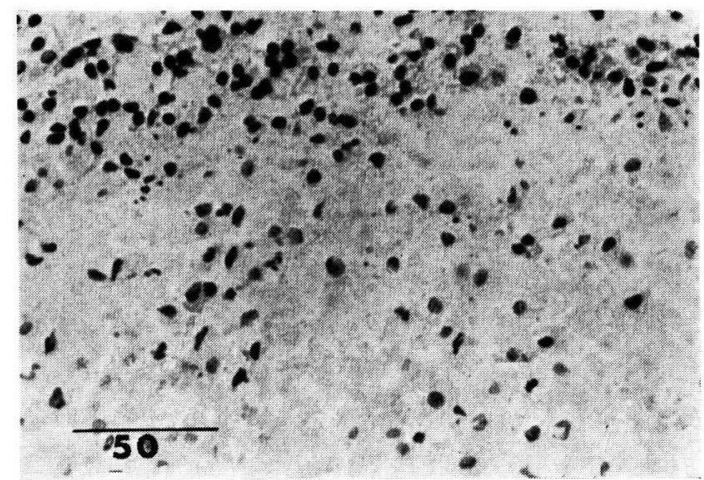

Fig. 2. Rat adrenal untreated

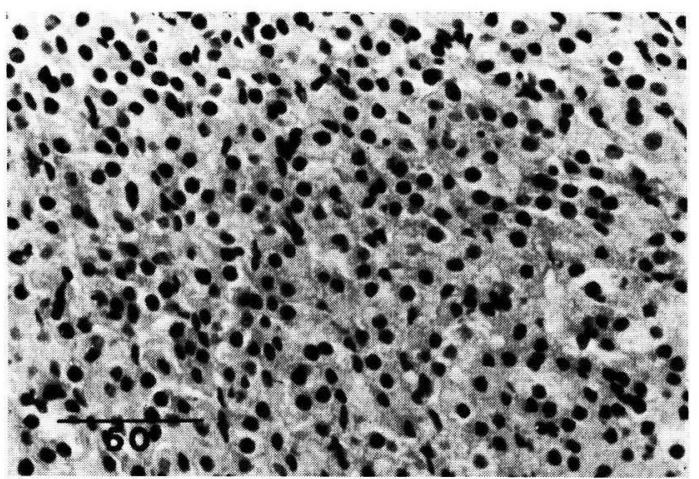

Fig. 4. 14 day aniline treated rat adrenal. Hypertrophied cortical cells with clear cytoplasm.

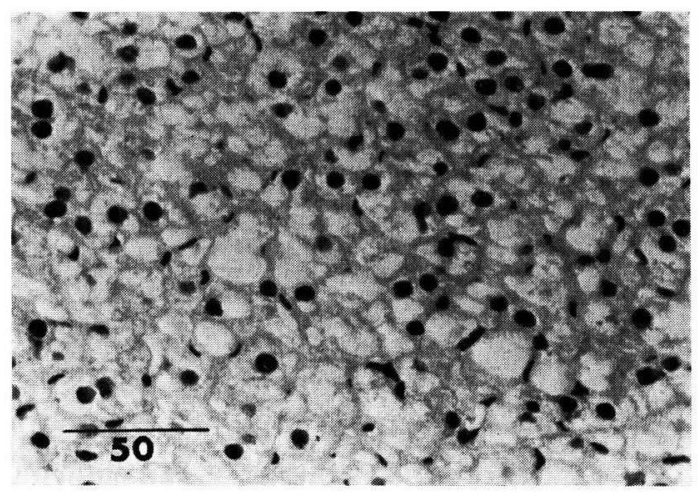

Fig. 6. Rat adrenal, untreated, 7 day organ culture with $0.02 \mathrm{IU} / \mathrm{ml}$ ACTH. Atrophic Z. glomerulosa and degenerating $\mathrm{Z}$. fasciculata.

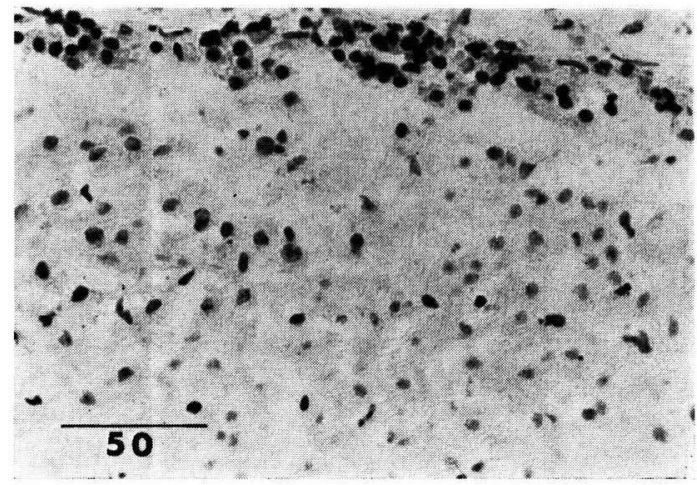


Fig. 7. Rat adrenal, untreated, 7 day organ culture with $0.2 \mathrm{IU} / \mathrm{ml}$ of ACTH. The outer part of Z. glomerulosa thickend.

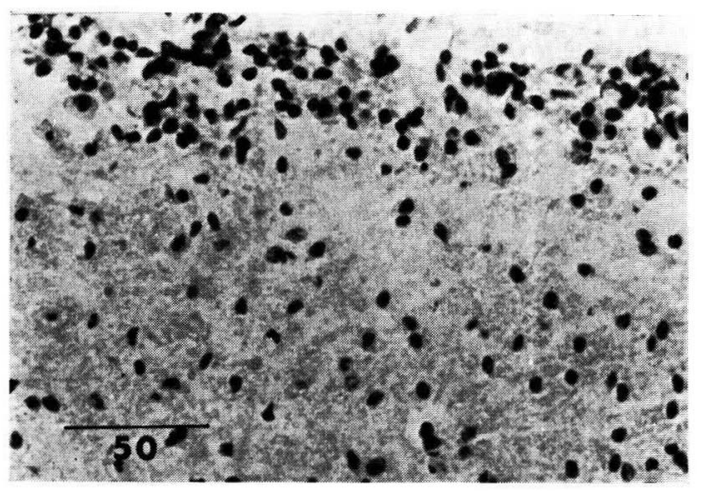

Fig. 9. Rat adrenal hyperplasia, 7 day organ culture with $0.02 \mathrm{IU} / \mathrm{ml}$ ACTH. Hypertrophied outer part of $\mathrm{Z}$. fasciculata and degenerating inner part $Z$. fasciculata.

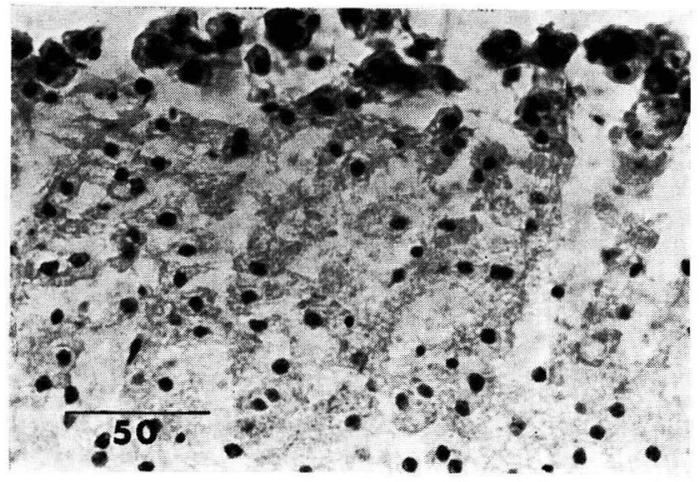

Fig. 11. Adenoma from Cushing's syndrome (Case 1). Mixture of "clear cells" and "compact cells'.

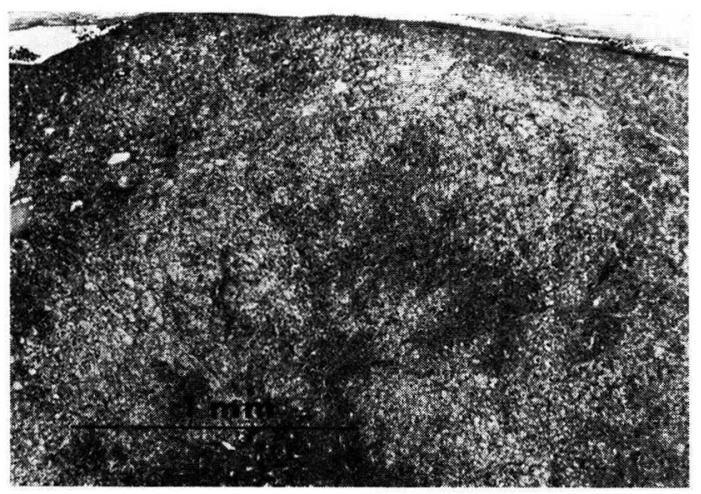

Fig. 8. Rat adrenal hyperplasia, 7 day organ culture without ACTH. Atrophic Z. glomerulosa and degenerating $\mathrm{Z}$. fasciculata.

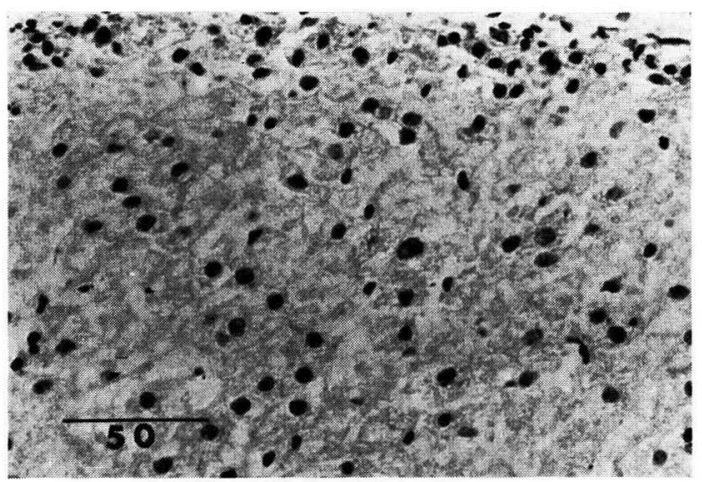

Fig. 10. Rat adrenal hyperplasia 7 day organ culture with $0.2 \mathrm{IU} / \mathrm{ml}$ ACTH. Note relatively maintained cortex cells.

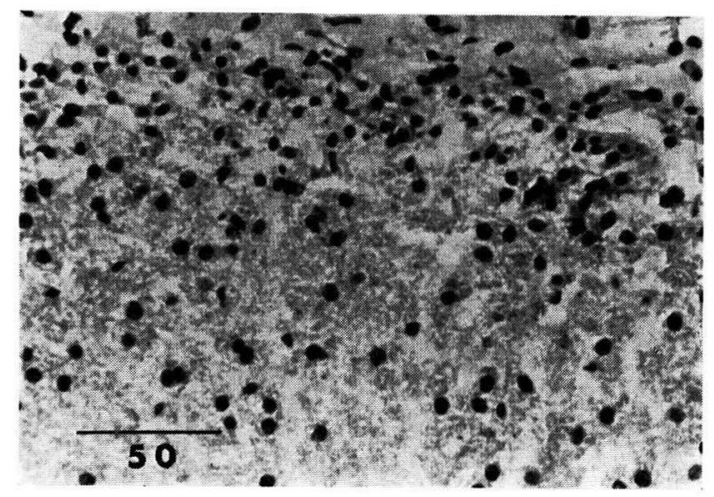

Fig. 12. High power view of the "compact cells". Note dense granular cytoplasm.

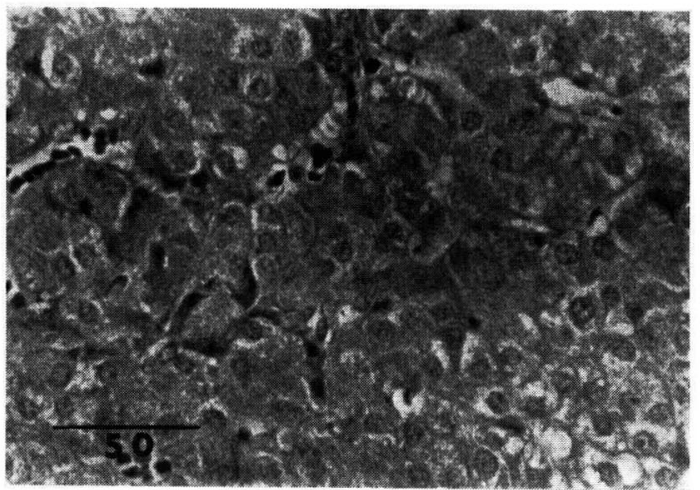


Fig. 13. Adenoma from Cushing's syndrome 48 hour organ culture without ACTH. Cytoplasm becomes clear. Nuclei condenced, occasionally show karyorrhexis.

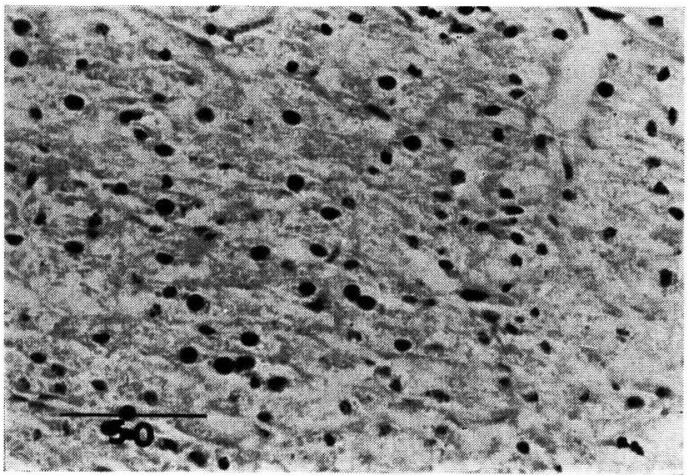

Fig. 15. Adenoma from Cushing's syndrome. 48 hour organ culture with $0.2 \mathrm{IU} / \mathrm{ml}$ of ACTH. Nuclei and cytoplasm better preserved.

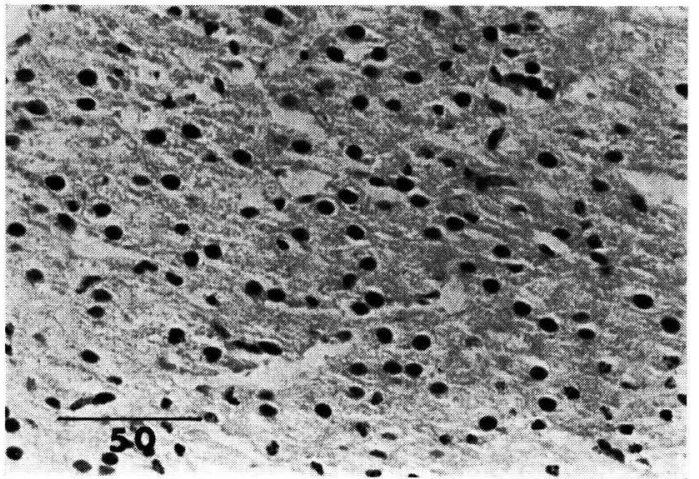

Fig. 17. High power view of the hypertrophied cells. Note enlarged clear cells with reticular cytoplasm and eosinophilic smaller cells.

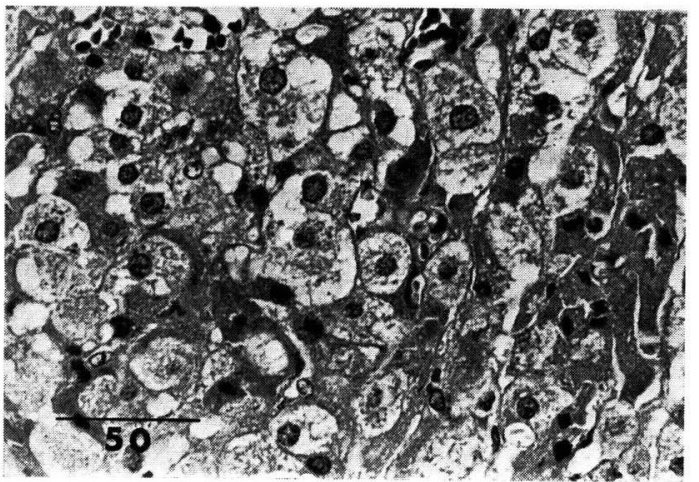

Fig. 14. Adenoma from Cushing's syndrome. 48 hour organ culture with $0.02 \mathrm{IU} / \mathrm{ml}$ of $\mathrm{ACTH}$. Generally degenerating.

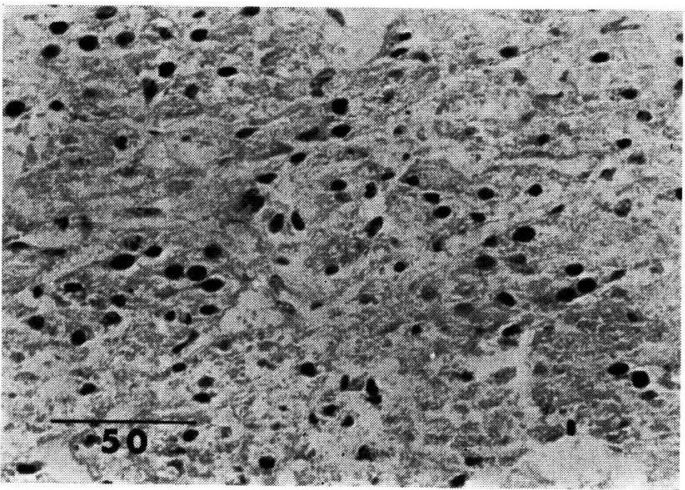

Fig. 16. Hyperplasia from Cushing's syndrome (Casa 5). Mixture of "clear cells" and "compact cells".

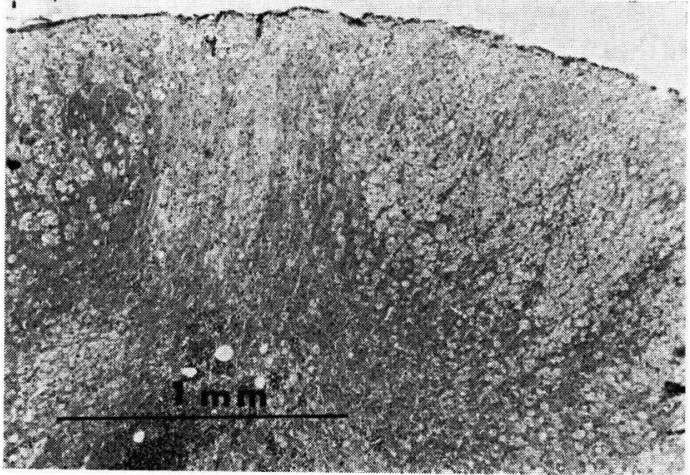

Fig. 18. Hyperplasia from Cushing's syndrome, 48 hour organ culture without ACTH. Hypotrophic changes are in both cell types.

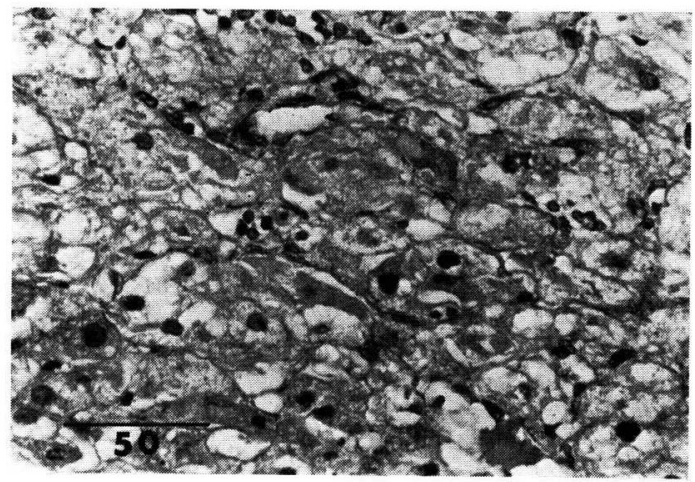


Fig. 19. Hyperplasia from Cushing's syndrome, 48 hour organ culture with $0.02 \mathrm{IU} / \mathrm{ml}$ of ACTH. Degenerating in both cell types.

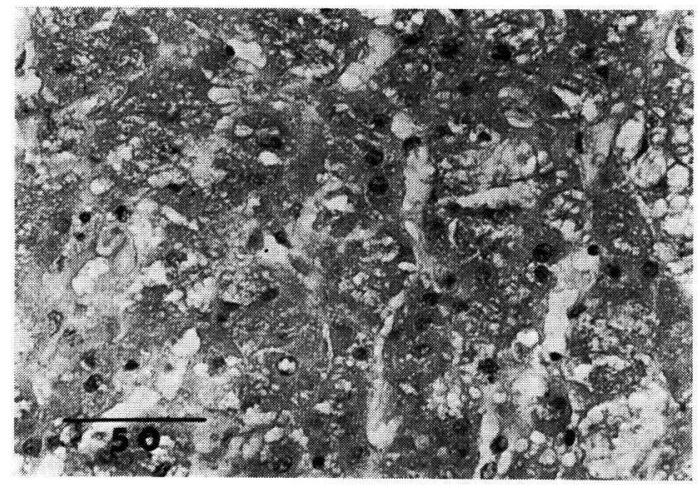

Fig. 21. Adenoma of primary aldosteronism (Case 6). Tumor cells consist of clear cells. Note the border line from adjacent normal adrenal tissue.

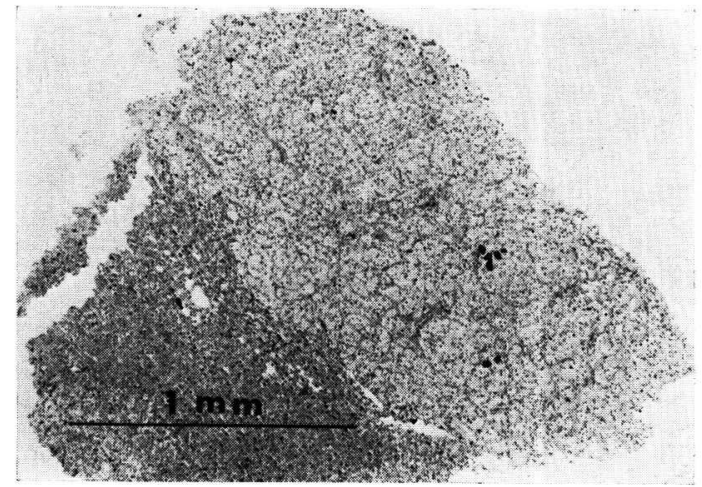

Fig. 23. Adenoma of primary aldosteronism, 48 hour organ culture without ACTH. Nuclear shrinkage andcytoplasmic degeneration.

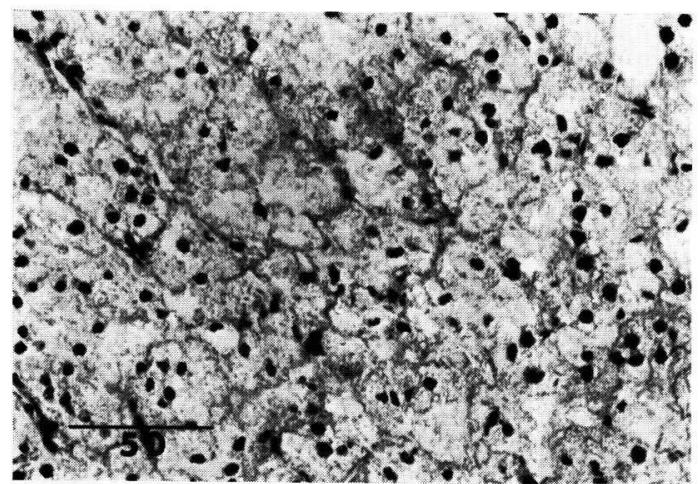

Fig. 20. Hyperplasia from Cushing's syndrome, 48 hour organ culture with $0.2 \mathrm{IU} / \mathrm{ml}$ of ACTH. well mainteind "clear cells" but less eosinophilic in "compact cells".

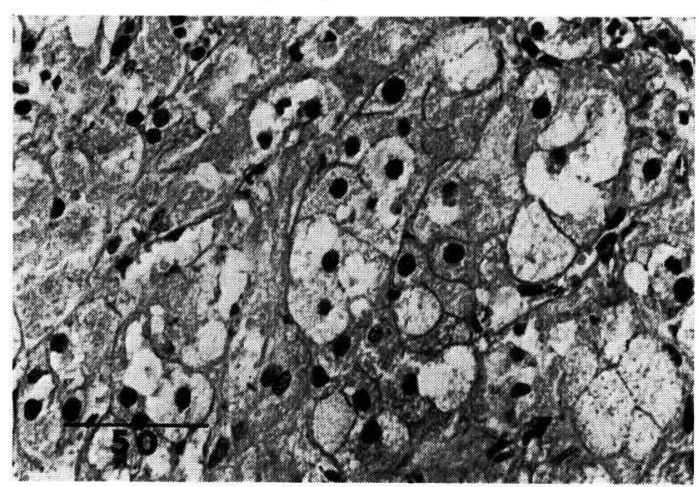

Fig. 22. High power view of the "clear cells" from adenoma of primary aldosteronism.

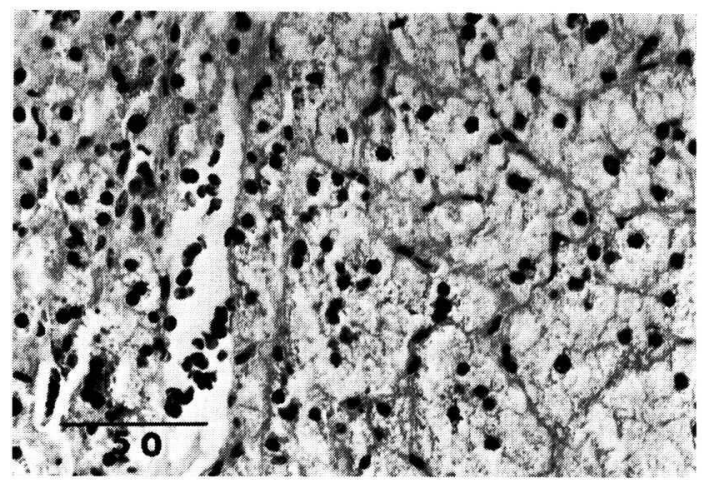

Fig. 24. Adenoma of primary aldosteronism, 48 hour organ culture with $0.02 \mathrm{IU} / \mathrm{ml}$ of ACTH. "clear cell" maintain the original patterns.

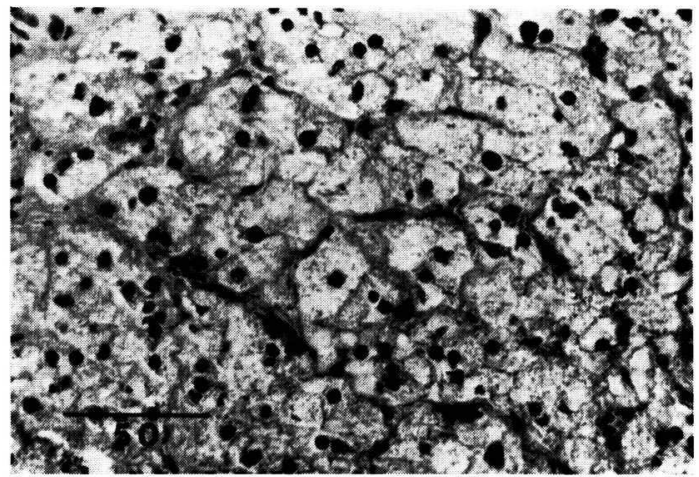


Fig. 25. Hyperplasia of primary aldosteronism. (Case 9) Encapsulated nodules consisted of "clear cells".

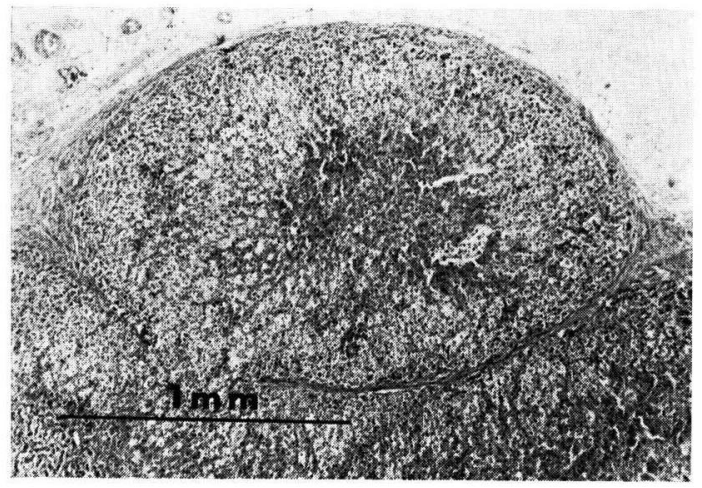

Fig. 27. Hyperplasia of primary aldosteronism, 48 hours organ culture without ACTH. A variety of shrinkage of nuclei and degeneragion of cytoplasm.

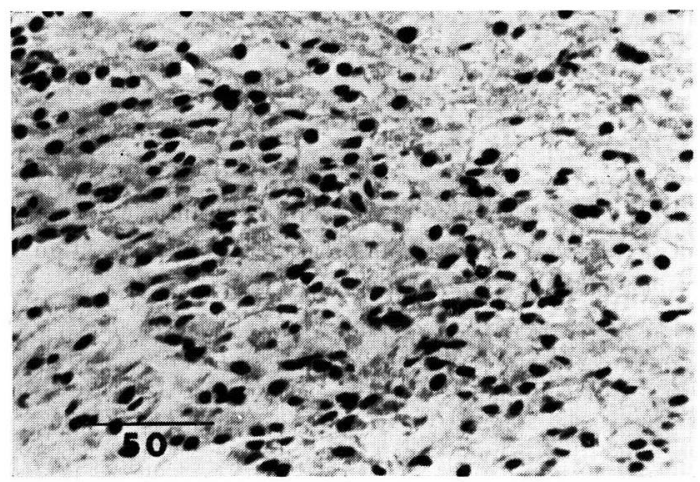

Fig. 29. Adenoma from adrenogenital syndrome (Case 11) Dark cells are developed.

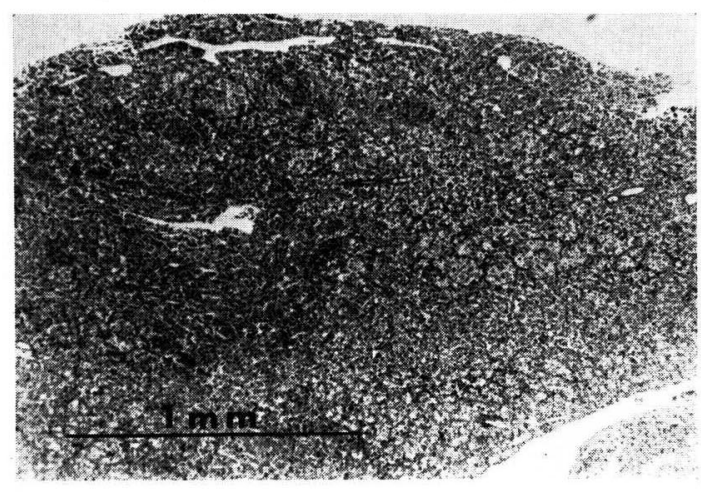

Fig. 26. High power view of the "clear cells". Hypertrophied cells form cell nests with fibrous connective tissues. Nuclei are small.

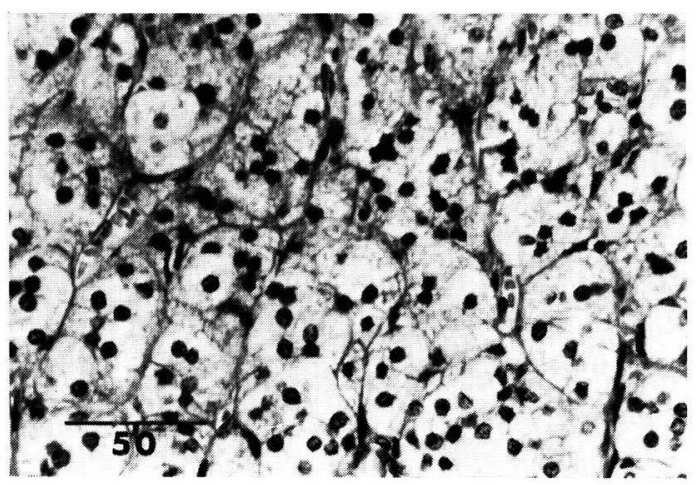

Fig. 28. Hyperplasia of primary aldosteronism, 48 hour organ culture with $0.02 \mathrm{IU} / \mathrm{ml}$ of $\mathrm{ACTH}$. Atrophic cytoplasm and nuclei remarkable.

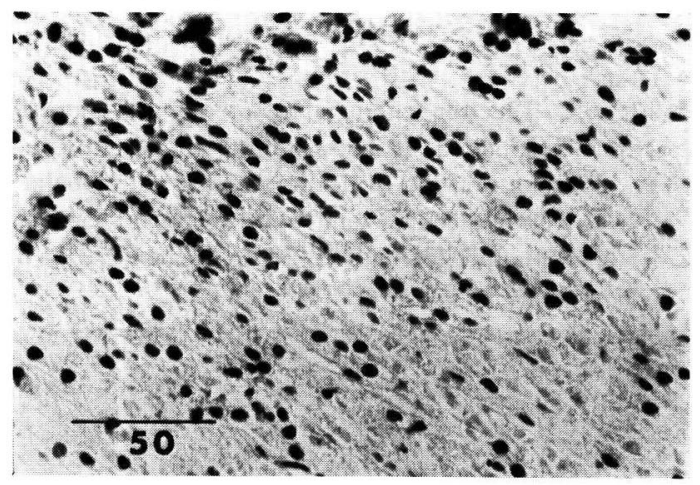

Fig. 30. High power view of the adenoma from adrenogenital syndrome. Small cells.

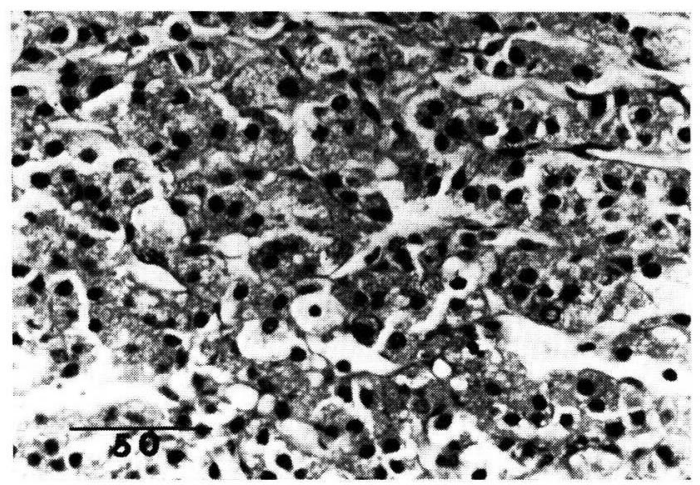


Fig. 31. Adenoma from adrenogenital syndrome, 48 hour organ culture with 0.02 ACTH. Cytoplasm become clear.

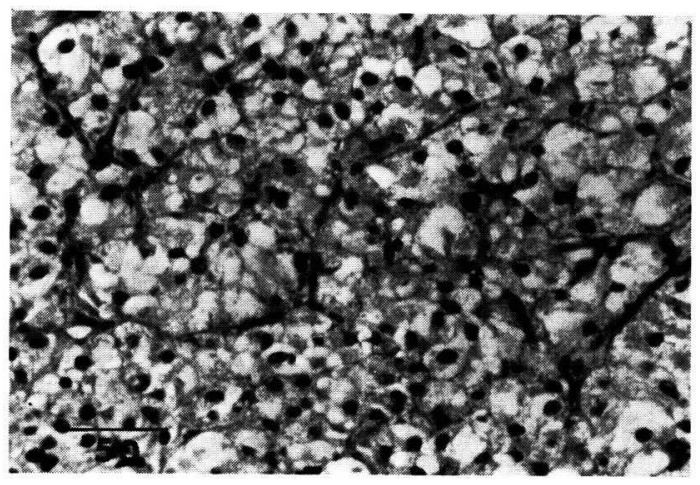

Fig. 32. Electron micrographs of normal adrenal Z. fasciculata, 48 hour culture without ACTH, showing round or oval mitochondria with tubular or vesiclar cristae and well developed smooth endoplasmic reticuli. M: mitochondria, V: vesicles, $\mathrm{N}$ : nucleus.

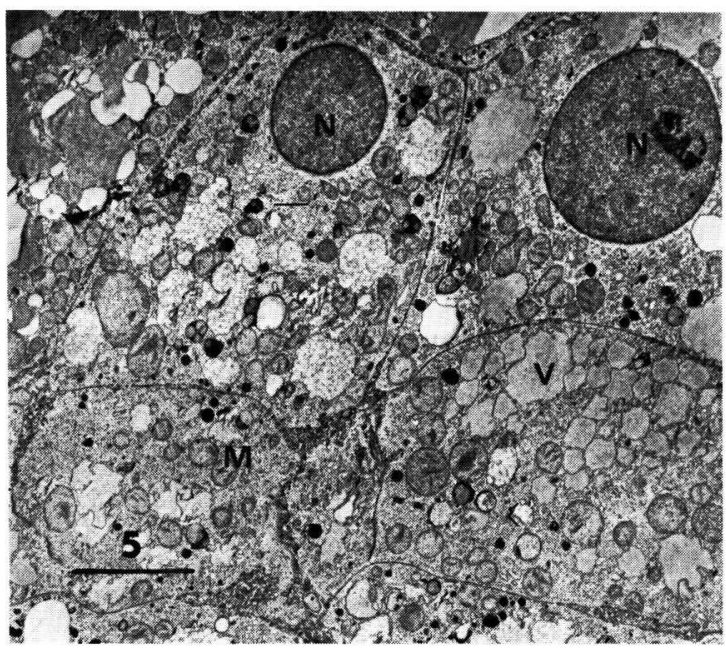

Fig. 33. Adenoma cells before culture. L: lipid droplets. Electron micrographs of adenoma from Cushing's syndrome (Fig. 33-36).

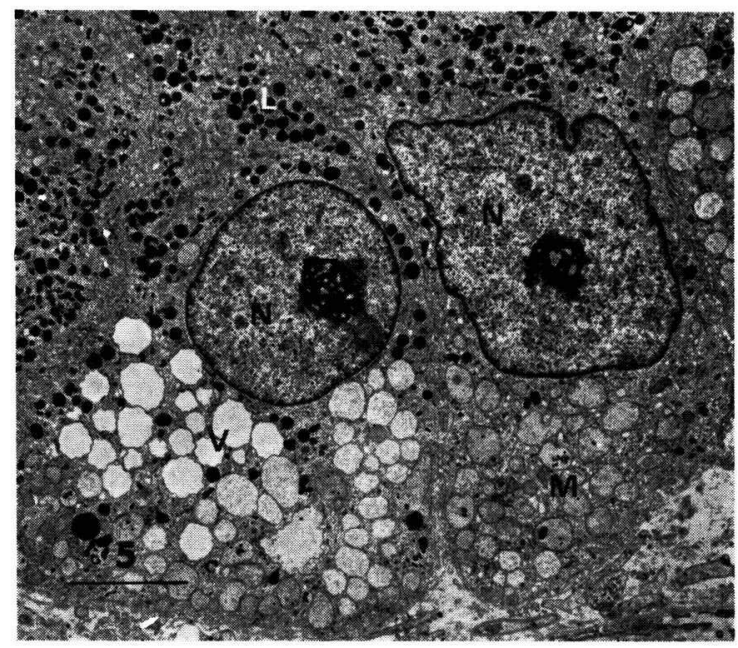


Fig. 34. Adenoma cells, 7 day culture without ACTH.

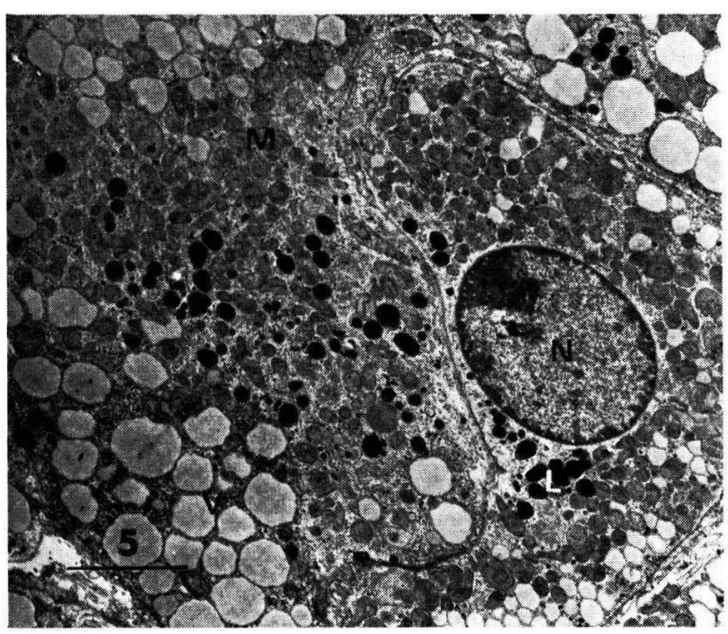

Fig. 36. Adenoma dells, 7 day culture with ACTH $0.2 \mathrm{IU} / \mathrm{ml}$. Mitochondria smaller. RER well developed. RER. rough-surfaced endoplasmic reticulum.

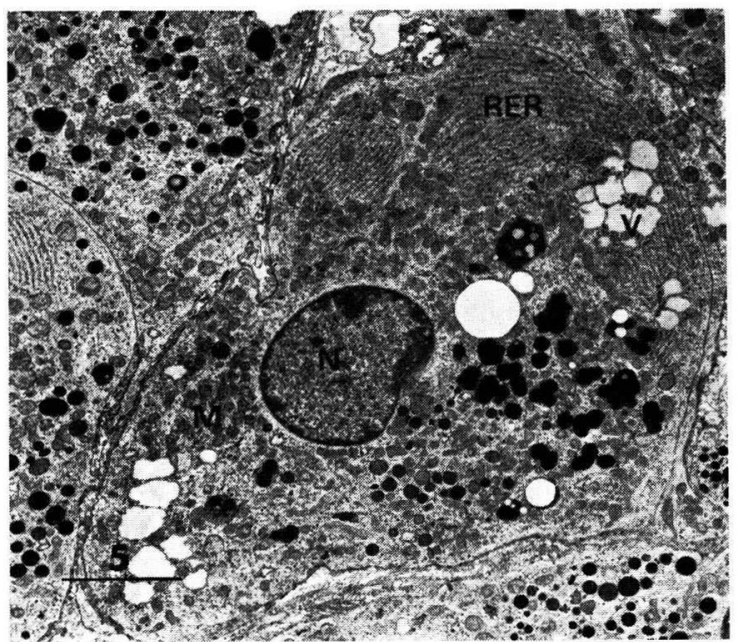

Eig. 35. Adenoma cells, 7 day culture with ACTH $0.02 \mathrm{IU} / \mathrm{ml}$. Note lipid droptets gather to center.

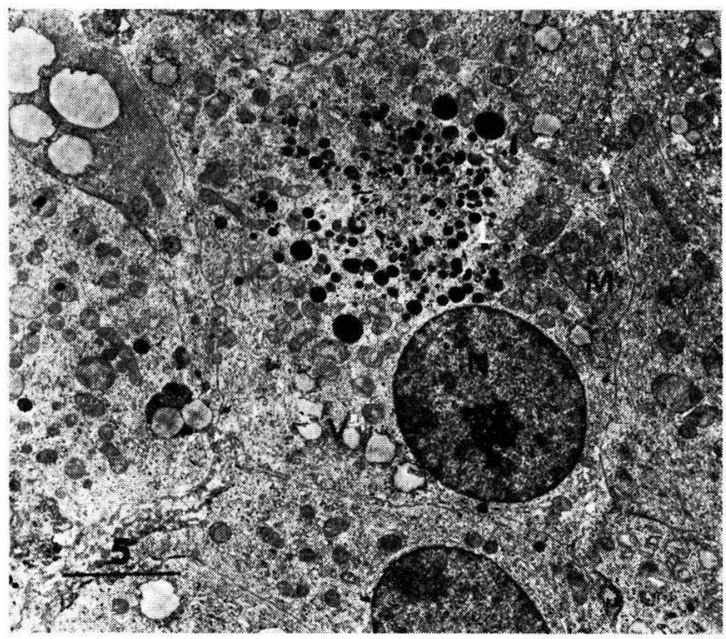

Fig. 37. Hyperplasia cells, 48 hour culture without ACTH. my: myelin-like lamellar structures. Electron micrographs of hyperplasias from Cushing's syndrome. (Fig. 37-39)

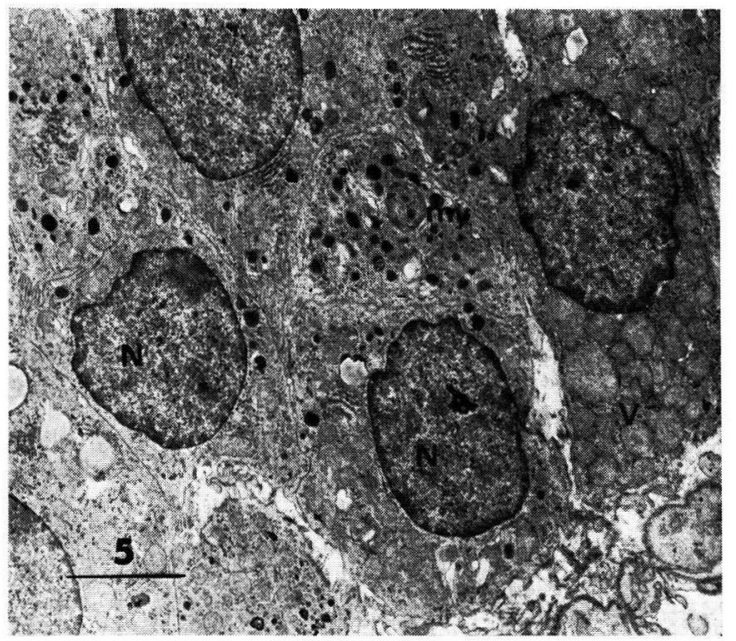


Fig. 38. 48 hour culture with ACTH $0.2 \mathrm{IU} / \mathrm{ml}$.

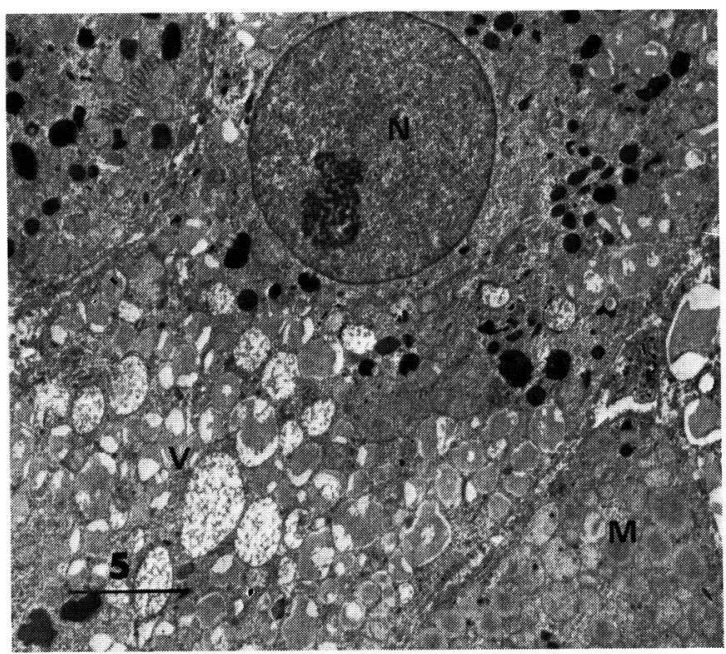

Fig. 40. Electron micrographs of non-tumor part of the adrenal from a case of primary aldosteronism with adenoma.

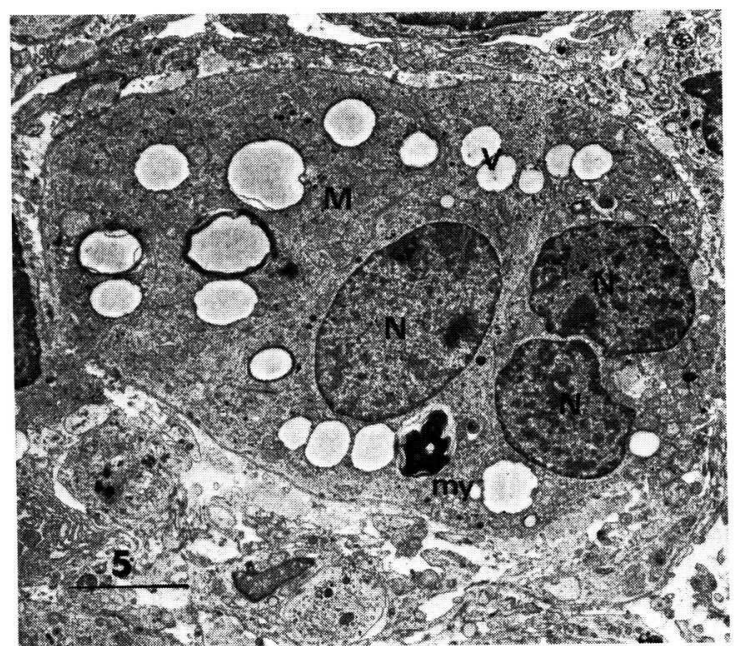

Fig. 39. 48 hour culture with ACTH $0.2 \mathrm{IU} / \mathrm{ml}$. cr: cristae of mitochondria.

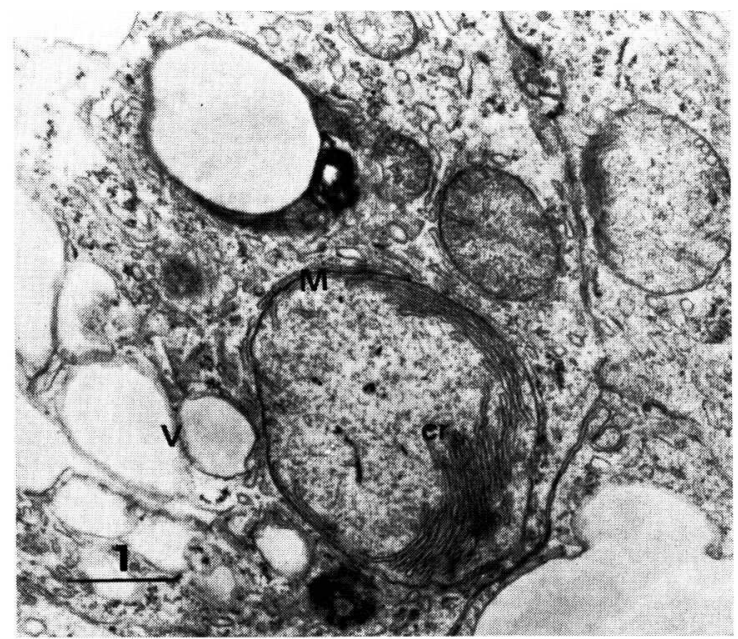

Fig. 41. Adenoma cells, 48 hour culture without ACTH. Electron micrographs of adenoma from primary aldosteronism. (Fig. 41-44)

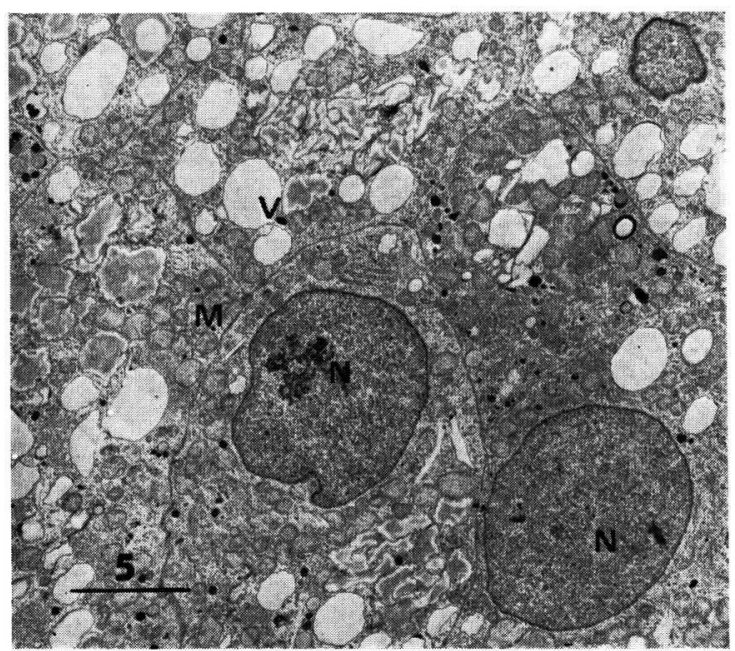


Fig. 42. A part of adenoma cell, 48 hour culture without $\mathrm{ACTH}$, showing a protrusion of the laminated structure into a vesicle.

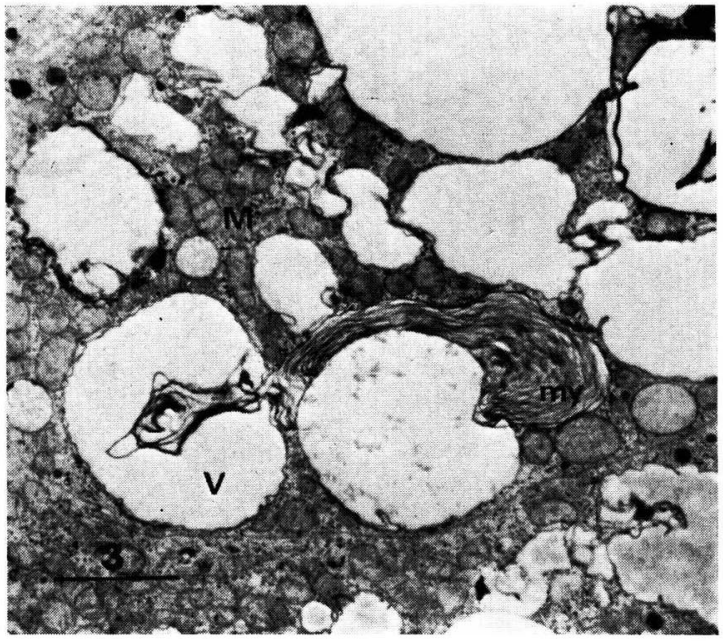

Fig. 44. A part of adenoma, 48 hour culture with ACTH $0.2 \mathrm{IU} / \mathrm{ml}$.

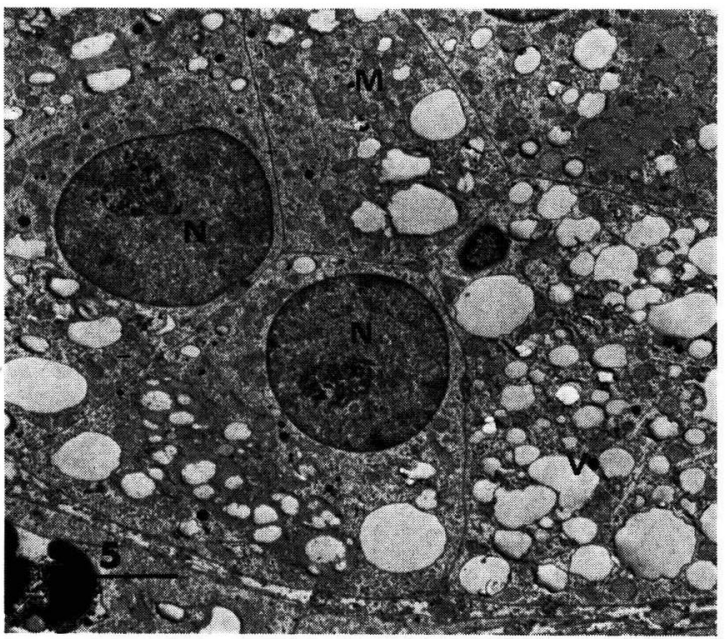

Fig. 43. Adenoma cells, 48 hour culture with ACTH $0.02 \mathrm{IU} / \mathrm{ml}$. Arrow; a close relation between myelin-like structure and vesicles.

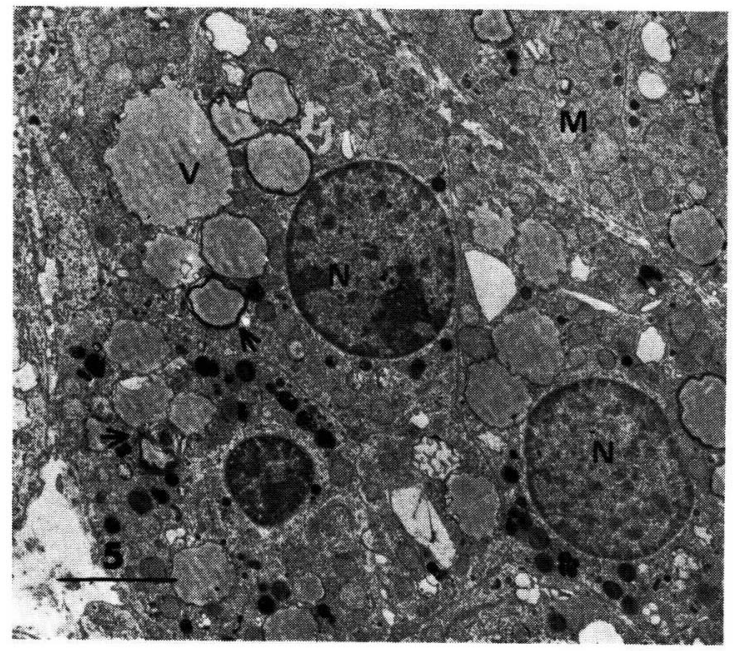

Fig. 45 Hyperplasia cells before culturer. Electron micrographs of hyperplasia from primary aldosteronism (Fig. 45-47)

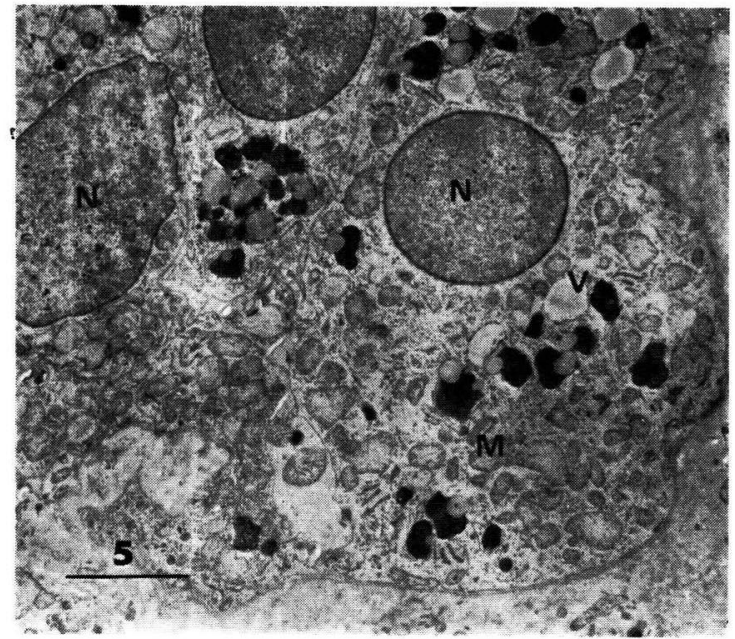


Fig. 46. Hyperplasia cells, 48 hour with ACTH $0.02 \mathrm{IU} / \mathrm{ml}$.

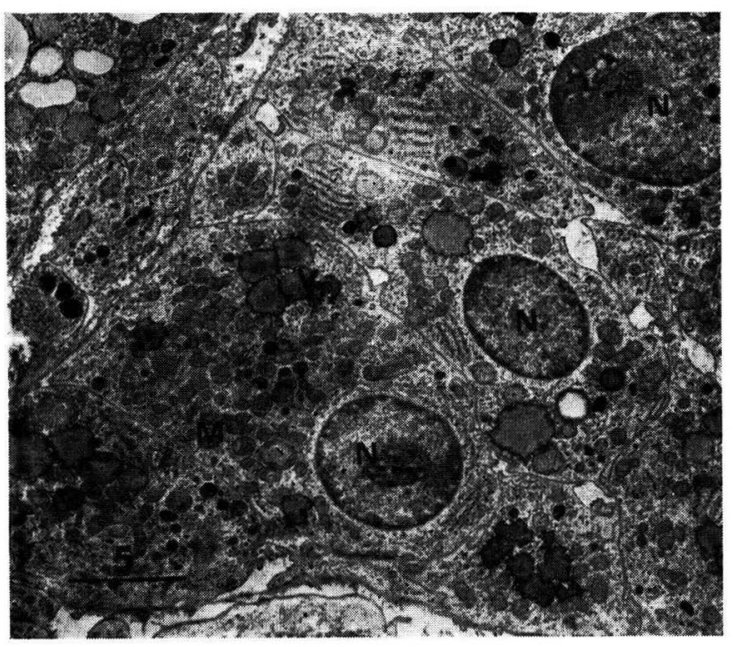

Fig. 47. Hyperplasia cell, 48 hour culture with ACTH $0.2 \mathrm{IU} / \mathrm{ml}$. R: ribosomes.

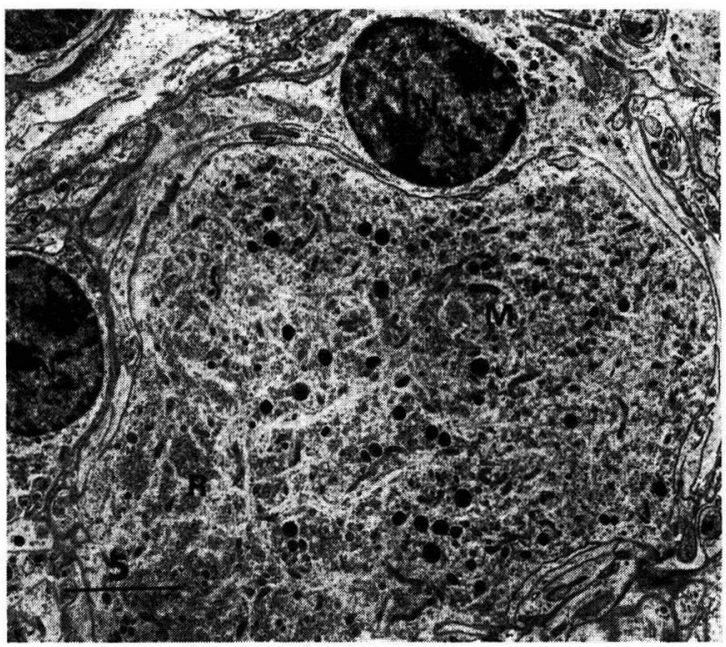

Fig. 48. Adenoma cells before culture. Electron micrographs of adenoma from adrenogenital syndrome (Fig48-53)

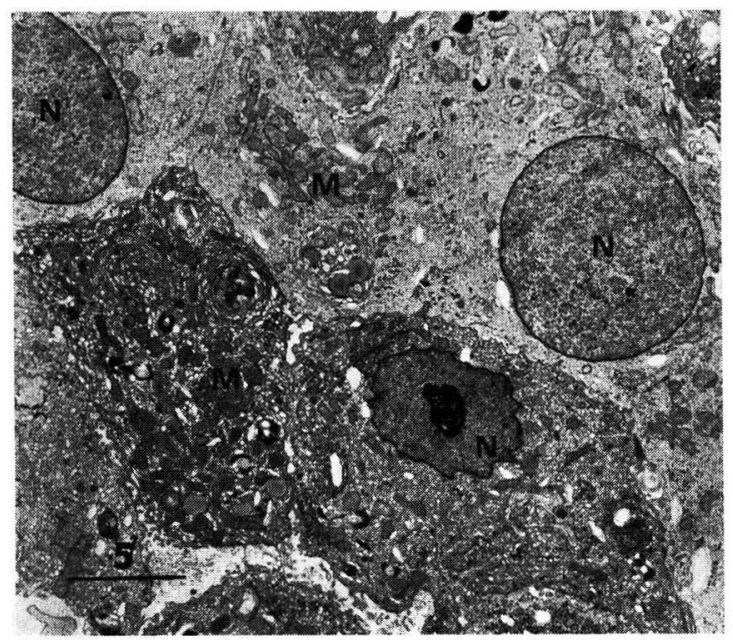

Fig. 49. Adenoma cells, 48 hour culture without ACTH. Note well developed SER.

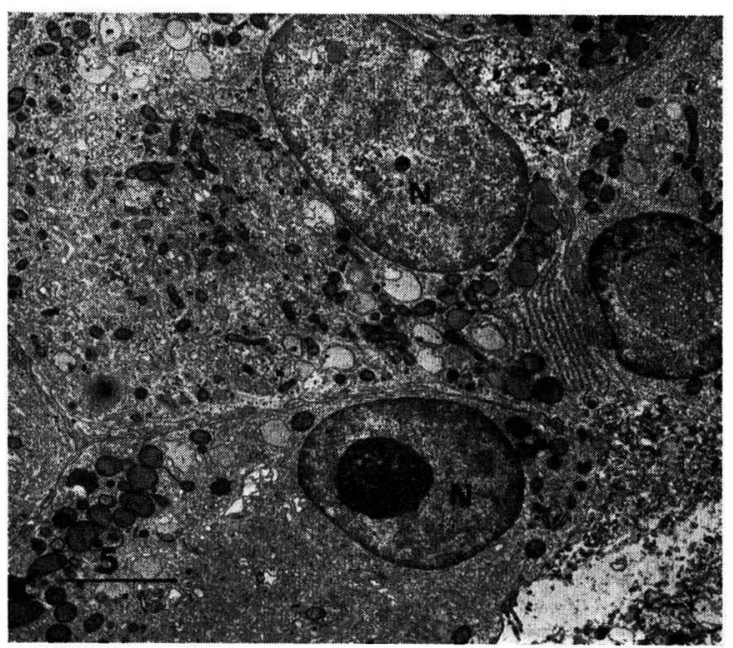


Fig. 50. Adenoma cells, 48 hour culture without ACTH, Myelin like structures circling a mass of ER.

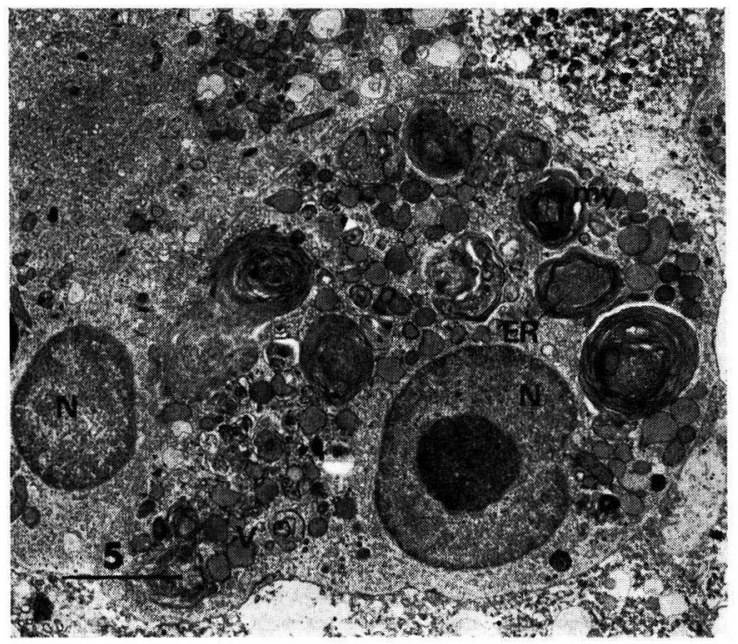

Fig. 51. Adenoma cells, 48 hour culture with ACTH $0.02 \mathrm{IU} / \mathrm{ml}$. Arrows indicate a streamrelated to the myelin like structure.

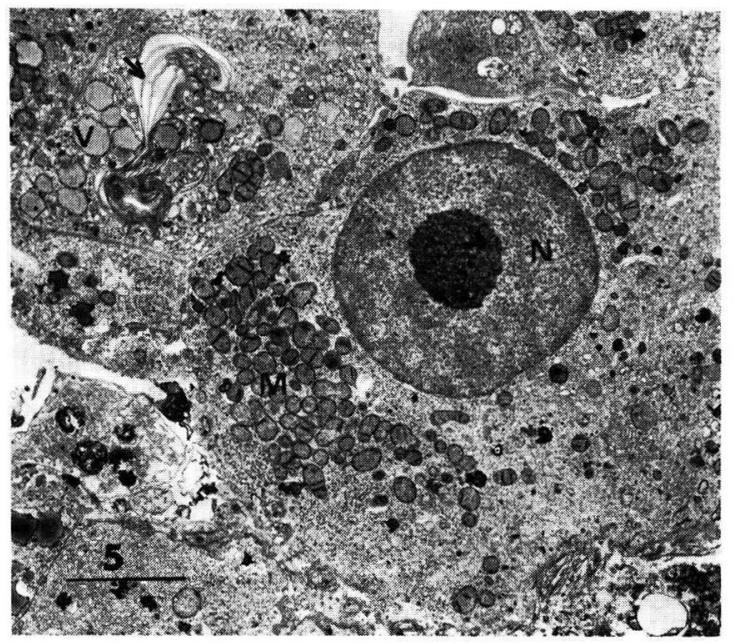

Fig. 52. Adenoma cells, 48 hour culture with ACTH $0.02 \mathrm{IU} / \mathrm{ml}$. Arrow: a close relationship between the myelin-like structure and ER.

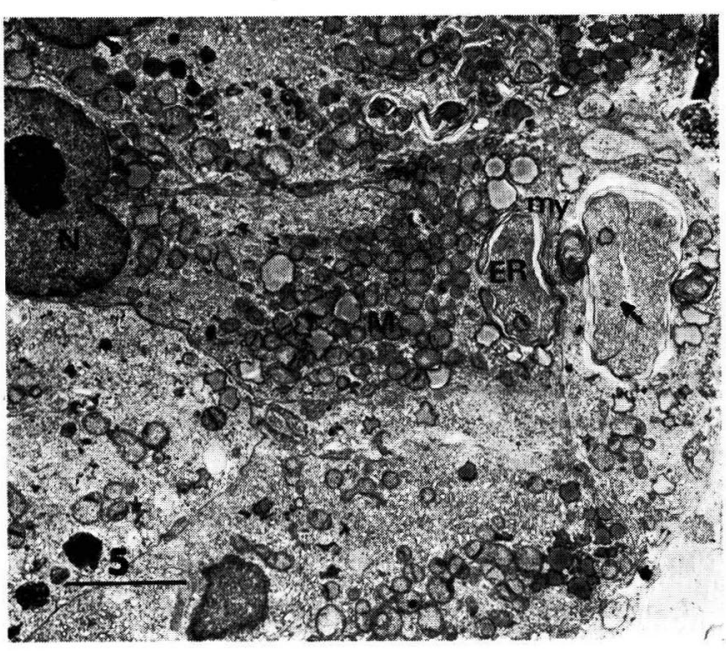

Fig. 53. Adenoma cells, 48 hour culture with ACTH $0.2 \mathrm{IU} / \mathrm{ml}$. Lipid increasing.

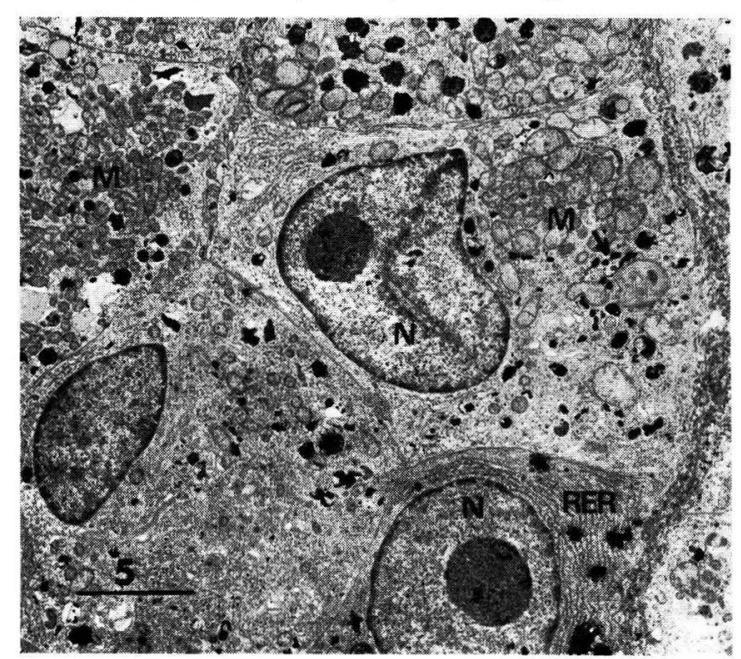


Z. glomerulosa の細胞は他の細胞に比し, やや小型多 角形で表面は平滑, 一部の細胞膜は microvill をもつ. 核は円形で核小体は明膫, 胞体には多数の脂肪滴（lipid droplet）をもつ. mitochondria は円形ないし卵円形で櫛 状あるいは柵状の cristae を有す，滑面小胞体 (smooth endoplasmic reticulum: SER 之略寸) は小さく発達は 中等度. Z. fasciculata の細胞の一般的特徵は Z. glomerulosa と同様であるが mitochondria が球形大型で 管状ないし胞状の cristae をもち matrix が豊富となり SER の発達は良好で粗面小胞体 (rough endoplasmic reticulum; RER と略す）も認められる. Z. reticularis の細胞では lipofuscin pigment granules がめだち mitochondria は棈円形のものが多くなる. SER よりも RER の発達が良い, 器官培養後の正常副腎皮質細胞: 一般に 胞体内に lysosome 由来と思われる空胞 (vesicles) が增 加し, free の ribosome が增す傾向はあるが気相や培養 液の pHなどの培養条件に特別の支障がなければ，48時間 から 7 日まで培養前の各小器官の基本構造はよく保存さ れていた（図32）。しかしながら ACTH $0.02 \mathrm{IU} / \mathrm{ml}$ 添 加により mitochondria は一般的に大きさを增し直径 2

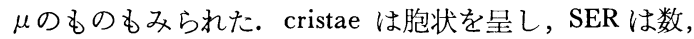
大きさともに增加を示した． Lipid granules はやや減 少, vesicles は増加するが, ACTH 非添加群と比較し て変化は軽度であつた。

b) Cushing 症候群より摘出した副腎皮質組織

i ) 腺腫 : (症例 $1,2,3$ )

培養前組織では細胞は一般に大型, 多角形で核は球形 である. mitochondria は大型円形ないし不正棈円形のも のが多く，大きさにかなりの差があり $5 \mu$ 以上の巨大な ものも観察された. Mitochondria の cristae は管状, 櫛状でとくに長軸に沿つて層状に配列 matrix が微細顆 粒状で豊富になつているものが多い，SERは発達が著し いが，vesiclesはがいして少ない(図33)。これらの基 本構造は ACTH 非添加で 7 日間器官培養を行なつた後 もよく維持され，ACTH 添加による影響は顕著ではな い(図34)。しかし，14日間器官培養後では，ACTH 非 添加群および $0.2 \mathrm{IU} / \mathrm{ml}$ 添加群ともに mitochondria は 著明に縮小し cristae は菲薄化していた。

一方 ACTH 0.02IU/ml 添加群においては 7 日ない し14日培養後も mitochondria は.その基本構造を良好に 保ち，SER は良好に発達し lipid granules は細胞により 差があり，ときに SER の周囲に集合してみられた（図 35).また ACTH $0.2 \mathrm{IU} / \mathrm{ml}$ 添加群で lipid granules
そSER は著明に増加している（図36）。

ii）過形成：（症例 4，5）

培養前の細胞では一般に核は円形で特記すべきことな く, 胞体内の小器官の発達は良好である. Mitochondria は多くときに集簇し大小不同もめだつ. cristae は管状, 滴状を示した．SER の発達は良好であるが，ときに直 径 $2 \mu$ 程度の myelin 様構造がみられた（図37）。

培養後もこれらの基本構造はよく保存されたが ACTH $0.2 \mathrm{IU} / \mathrm{ml}$ の添加により lipid granule はさらに大型と なり系粒体胞が緊満して円形となり, cristae は滴状と なる. SER の発達も良好となり lipid granule が豊富 にみられる細胞も出現する (図38). 強払大で肥大した mitochondria は並行して配列するか滴状の cristae がみ られる(図39)。また直径 $3 \mu$ 程度の vesicle が一般的 に増加する。

c）原発性アルドステロン症

i ) 腺腫: (症例 $6,7,8$ )

培養前の組織は大型で多角形の細胞よりなりたち， 核には特記すべき所見はないが，広い細胞質は多数の vesicle て占められ, mitochondria, SER などの小器官が 少ないことが特徴である. mitochondria は円形ないし棈

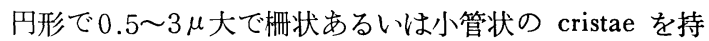
つが Cushing 症候群の腺腫と比較して柵状の cristae を もつものが多い，腺腫細胞拉よび腺腫以外の部で正常副 腎組織とみられる細胞内に vesicle に接して myelin 様 層構造（いわゆる spironolactone body）がみられる（図 40）のがきわめて特徵的である. 2 日間培養後の観察で もこれら基本構造はよく保たれるが（図41），ときに前 述の myelin 様構造の変形, その一部が空胞内に突出し ている像がみられた（図42）。Mitochondria は ACTH $0.02 \mathrm{IU} / \mathrm{ml}$ 添加（図43）では対照とほほ同様であつた が，典型的な myelin 様構造は少なくなり， vesicle との 間に移行がみられ (失印)，内容が均等にやや電子密度の 増加した物質でみたされるようになるのに比し，ACTH $02 \mathrm{IU} / \mathrm{ml}$ 添加では mitochondria はやや大きくなり vesicle も增している（図44）.

他方，培養前後で mitochondria と vesicle の間にも 相互の機能的関連性を示唆するごとき形態的な変化がみ られた。とくに前述の myelin 様小体のある附近では mitochondria と vesicle は隣接して存在し, 何らかの物 質の移動を推定させる像が多かつた。

ii ) 過形成：（症例 $9,10 ）$

培養前の組織ては紼胞は円柱状のものが多いが，核。 
核小体には特記すべき所見はない，Mitochondriaは呿お

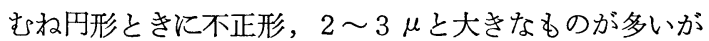
一般に大小不揃いである. Cristae は管状ないし泡沫状の ものが多く，周辺に配列する. Lipid granule は非常に多 い(図45)。ACTH 0.02IU/ml 添加では, mitochondria は正常副腎のそれ (Z. glomerulosa) 飞似て，円形ない 乙卵円形で值経 $0.5 \mu$ 程度の大きさとなり, cristae は線 状となり matrix の量は減少する.

Lipid granuleは減少し密度が低下した不正形の小体と

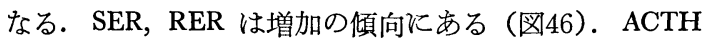
$0.2 \mathrm{IU} / \mathrm{ml}$ 添加では mitochondria は著しく縮小して線 状様となり cristae はほとんど消失, 明らかに萎縮した ことを示した. Dense granule および free ribosome は 增加した（図47).

d) 副腎性器症候群

i ) 腺腫 : (症例11)

培養前の組織で腫瘍細胞は多角形, 中型のものが多 く，核は円形，核小体は density の高いものが多い. 胞 体内の小器官の発達は良好で, とくに mitochondria の 数が多く, 集簇してみられ円形ないし棈円形で, cristae は線状，matrix の密度は高い，SER，RER，の発達はき わめて良好であつた。しばしば RER が同心円状に配列 し不完全ながら myelin 様構造を示した. Vesicles, lipid granules はほとんど認められない(図48).

ACTH非添加群では培養後核小体が円形で大きくなつ ているほか, mitochondriaなどの基本構造に著変はない が，SER はRER よりも增加しており（図49），一部で は大小の同心円状の myelin 様構造がみられた（図50). ACTH $0.02 \mathrm{IU} / \mathrm{ml}$ 添加群では前述の myelin 様構造沉 流動的変化を認め (矢印), その周辺に接してRERの著 しい集積像がみられる（矢印）。またときには集積した RER の周囲に myelin 様構造の一端が認められた（図 51, 図52). ACTH 0.2 IU / $/ \mathrm{ml}$ 添加群では大小不正形の lipid granule の数は増加し SER, RER ともに発達は良 好となつていた. Mitochondria はやや大きさを増し， 散在性にみられ cristae も管状, 泡状のものもみられる が基本的には培養前の構造を維持していた。変形した myelin 様構造はしばしば lipid と隣接して認められた （矢印）（図53）.

\section{考按}

最近，組織培養を応用した基礎的および臨床的研究が いろいろの分野で盛んに行なわれるようになつてきてい る. 組織培養の中では最も単純化された細胞培養が理想 であるが，in vitro に長期間順応している細胞株は必ず しも本来の生物学的特性を継承しているとは限らない。 また内分泌学的研究法として行なわれている組織のslice を短期間 incubate する方法も本来の組織の機能を忠実 に in vitro で再現しているか否かはなはだ疑問であ る. そこで組織の単位で機能と形態の関係を維持させつ つ in vitro の実験を行ならために登場した器官培養法は 多くの批判を残しながらもやはり捨て難い有用性を持つ ている.

副腎のような内分泌蔵器の器官培養は各種 hormone の target organ としての機能の解明，すなわち下垂体の 影響, 生体内での feed back の問題, さらには副腎皮質 細胞そのものの中での機能の問題など他の臓器と比較し て特異な点が多く実験方法についても，また実験結果に ついてもきわめて慎重に検討することが必要である．副 腎の器官培養に括㤝る利点は feed back system や下垂 体 hormone の支配から解放された実験ができることに ある、また培養液をはじめとし培養条件を変えて組織を 維持し，さらに培養された組織について電子顕微鏡的観 察, 組織化学, 免疫化学的方法, 微量化学分析法などの 検索を行ならことにより細胞内小器官形態と機能の解明 の可能性があると判断し，本研究を行なつた.

副腎組織培養の歷史：Carrel and Burrows ${ }^{20)}$ (1910) がはじめて犬，猫，かえるの副腎をそれぞれの血清を 培養液として培養することに成功して以来，Bulliard ${ }^{211}$ (1923), Ssipowsky ${ }^{22)}$ (1929), Kasahara ${ }^{23)}$ (1933), Lux et $\mathrm{al}^{24)}$ (1935)，Knöl125)（1937）らが，いくつかの方 法で副腎組織の組織培養を試み，その形態を観察してい る.

器官培養法では Barker and Carrel ${ }^{26)}$ (1939) がはじめ て人工培養液で猫の副腎の培養を試みたが，2 日後には 変性壊死を抗こしている. その後，Martinovitch ${ }^{27) 28) 29)}$ (1951，1953，1955)が器官培養を試みており，Schaberg 30) 31 32 323334) 35)（1955）らはラットの副腎を器官培養し一 連の詳細な報告をし，ACTH あるいは下垂体前葉組織 によつて，幼若ラットの皮質の Z. glomerulosa から Z. fasciculata に分化すること， corticosteroid が增すとの ベた.

Trowel1 $^{36)}$ (1959)は stainless steel の grid を用いた 方法でラットの副腎を器官培養したが，Z. fasciculata は変性壊死に抢ちいり ACTH と ascorbic acid の添加 る無効だつたと報告している.

Kendall et $\mathrm{al}^{38)}(1959)$ はハムスターの副腎の器官培養 
を行ない，1 気圧空気あるいは低酸素分圧でも維持可能 と報告しているが，Macdougall and Coupland ${ }^{39)}$ (1967) は Trowell の方法を改良し, 高圧酸素下において各種の 組織の器官培養を試み，酸素分圧に対する組織の反応は 臟器によつて異なることを認めた。とくにラットの副腎 組織の器官培養に执いて1気圧の下では䯣質と皮質の Z. glomerulosa はよく保存されるが皮質の残りの部分は 強い变性に陷るのに対し，2気圧の下では皮質は全体に よく保存されるが䯣質は強い変性に陥ることを認めた。

Kahri ${ }^{40)}$ (1966) はラットの胎生期副腎を Fell の方法に より長期間器官培養し ACTH の添加により epithelial cell が形態学的に Z. fasciculata に似ることを報告，さ らに ACTH の濃度は $0.02 \mathrm{IU} / \mathrm{ml}$ が至適で $0.2 \mathrm{IU} / \mathrm{ml}$ 以上の高濃度ではむしろ抑制されると報告している.

動物の副腎腫瘍組織の組織培養については Buonassi

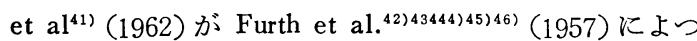
て作られたマウスの functioning tumor cell を monolayer 培養し，培養細胞のホルモン産生能を報告したのにはじ まり, Stollar et $\mathrm{al}^{48)}$ (1964) と Kowal and Fiedler ${ }^{48}$ （1968）はこの培養細胞が ACTH cyclic AMP に刺激さ れることをみ，これらの細胞が ACTH の in vitro の研 究に有用であると報告した。 またNeville et al.499(1968) は CE 株マウスの副腎皮質腫瘍細胞を19日間 cell culture し，培養細胞に dehydrogenase system が残つてい ることを autoradiography で証明した.

ヒト副腎細胞の組織培養については, Bloch ${ }^{50)} ら(1965)$ が胎児副腎組織をTrowell 法により器官培養（4〜8 日間) し progesterone から cortisol への変化を観察し Stark et al ${ }^{51)}$ (1965) は同様な方法で培養細胞の corticosteroid 産生能は培養 3 日目から 8 日目までが最大で あり，胎児副腎由来の培養細胞が ACTH の刺激をうけ ることを報告した. Milner and Villee ${ }^{52}$ (1970)は Kahri と同様の方法で，胎児の副腎を器官培養し，ACTH 0.1 $\mathrm{IU} / \mathrm{ml}$ を培養液に添加し，その影響を観察している. 形態学的には ACTH により microvilli の形成 SER の 膜の proliferation がみられ mitochondria の内膜は空胞 を形成する. 生化学的には exogenous progesterone の cortisol への合成が ACTH により増加すると報告して いる. 一方，ヒト成人副腎組織については Jones et al. ${ }^{54)}$

（1970）が，乳癌患者の副腎摘出組織よりZ. reticularis 組織および Z. fasciculata 組織をとりだし Trowell 法 により器官培養し，これに pregnenolone を投与し，培 養液の cortisol, DHA (dehydroepiandrosterone), DHA sulphate の三者を定量した。

Chemical defined media 使用の器官培養については Villee ${ }^{53)}$ (1966) が胎児副婜について Trowell 法を用い て24時間培養に成功している。

著者はこれらの歴史的背景を考虑し， Tazaki et al. 扣よび尾関の行なつた方法を採用した。すなおち 2 気庄 の空気炭酸ガス混合の気相はすでに前述の Macdougall らが副腎で応用成功していること，また Jones et al. が ヒトの副腎の培養で hormone の生合成過程の一部を証 明していることに着目したためである．副腎過形成の動 物実験について：動物の実験的副腎皮質過形成について は Kovacs ${ }^{55)} ら$ (1971) がラットに aniline を投与し, 副腎皮質に脂質過形成をつくり，電子顕微鏡的所見をふ くめて，その形態を観察し，その成因沉ついてのべてい る.すなわち aniline 投与により副腎皮質に lipid droplet と cholesterol 結晶の蓄積がおこり, mitochondria の変。 性, SER の増大, Golgi 装置の抎張, lysosome の增加 がみられたという。これらの変化は Prader and Gurtner ${ }^{56)}$ ，Camacho ${ }^{57)}$ らの報告している新生児の congenitallipoid-adrenal hyperplasia や Racela ${ }^{58)}$ らとの他の報 告 ${ }^{59960)}$ にみられる aminoglutethimide 処置動物の副腎 皮質の変化にほぽ一致する.

また aniline 投与による皮質過形成の電子顕微鏡的钼 察で mitochondria の変性, SER の増大は, ACTH 投与 あるいは stress 下の副腎皮質の変化 ${ }^{61) 62(63) 64)}$ と全くよく 類似するが，脂肪の蓄積はなく逆に著明な脂肪の減少が あるという，以上の理由から Kovacs らは aniline 投与 による皮質過形成の成因に関し aniline が steroidgenesis の初期の段階で inhibiter として働き，その結果 circulating corticoid が減少し, ACTH 分泌が増加し, 皮質 の過形成が生じるとのべている.

著者はこの Kovacs の研究を追試し，全く同様の絬果 を得たとこで著者はさらに進んでこの過形成組織を in vitro に維持しうる条件を設定するために器官培養を 行なつて，七ト副腎皮質過形成，腫演の培養のための予 備実験とした。

培養組織を光学顕微鏡的に観察すると，培養期間が 長い万が変性壊死の傾向が強くなるが，7日間までは ACTH の添加により十分に良好に維持された．無処置群 の器官培養では ACTH 非添加群では7 日間培養では皮 質表層が一部維持されているが内層は活とんど壊死に陥 るのに対し ACTH 添加群は皮質表層はほとんど正常に 保たれ，内層の細胞は淡明化したものも少なくないが 
ACTH 0.02IU/ml で保存良好であつた. 過形成組織の 器官培養についてはいまだ報告がないが，本研究では無 処置正常副㹂組織よりも良好飞保存され, ACTH 添加 によりさらに組織保存はよくなつた。 この場合 ACTH の濃度は $0.2 \mathrm{IU} / \mathrm{ml}$ の才が良好であつた。これらの所 見は Z. fasciculata の維持に ACTH が必要であるとい う Kahri の教兄を支持，また過形成組織の培養所見も過 形成がラット生体内での ACTH 過剩分泌によることを 考孚れば，培屋中もその形態の維持のために ACTH が 必要であり, 正常組織よりも, より高濃度の ACTH 添 加が要求されていると理解される.

ヒト副婜皮質過形成および腫瘍組織の培養について： Jones はヒト副堅皮質の Z. fasciculata と Z. glomerulosa を器官培養し exogenous pregnenolone の代謝に打ける ACTH の影響について報告し, cortisol は Z. fasciculata そ Z. reticularis で産生されるが，ACTH の投与では Z. fasciculata の組織のみ影響される.

DHA (dehydroepiandrosterone), DHA sulphate Z. reticularis で産生されるが ACTH でさらに刺激され たという.

ACTH の副腎に対する作用については Smith ${ }^{65}$ (1930) の下垂体摘出ラットの実験以来, 多くの報告がされて いて steroidogenesis に対する ACTH の役割も Haynes and Berthet ${ }^{66)}$ (1957) の仮説以来, 生化学的観察によ りその解明がすすめられている. 現在 ACTH の作用の 場として最も考えられているるのは紐胞膜で，そこで cyclic AMP を形成するといわれる (Haynes ${ }^{67}$ (1958)：

Pastan et $\mathrm{al}^{68)}$ (1966) : Tanton et al ${ }^{69}$ (1967) : GrahameSmith et $\left.\mathrm{al}^{70)}(1967)\right)$. さらに cyclic AMP が internal inducer として働き， mitochondria 内の酵素により SER に密着した cholesterol から steroid の生合成がおこる と考光られる.

電子顕微鏡的钼察を駆使しても，形態から機能を論ず ること, あるいは細胞の生化学的な变化を形態と閉連つ ケることはむずかしい，形態の変化は代謝過程の変化よ り遅れることが多く, 生化学的変化のあるものは超微形 態学的観察でもその動きを定量的にとらえることが不可 能であるが，定性的あるいは質的な検討は， mitochondria をはじめとして SER, RER Golgi 装置の変化から可能で 西り, 当しろ樋々の細胞の機能, 動的状態は生化学的方 法よりも忠拣に表現しているとい方る.

以上のことから，ヒト副腎機能九進組織の培差に拈け る ACTH の作用をみると, 腺腄組織では, 腄瘍細胞の autonomy のために ACTH の影響はあまりみられない が，著者の実験で原発性アルドステロン症の腺腫細胞に 抢ける mitochondria は ACTH 添加により培養前の性状 がよく保存されるほか, myelin 様層構造に変化を与兄る など, 腺腫でもある一定の濃度ではACTHの影響を受け らることが示された。このことは Newton and Laragh ${ }^{71}$ (1968) Slaton et al. ${ }^{72)}$ (1969) の臨床的な報告, およ び Hainsworth and Grant $^{73)}$ (1971) の in vitro の実験 で原発性アルドステロン症腺腫が ACTH の投与により aldosterone の分泌が增すといら実験結果と関係し，自 律性を持つはずの腺腫細胞も humoral な影響を全く受け ないとはい竞ないこと示している.

副腎性器症候群の腫瘍組織は ACTH により RER の 増大と後述する myelin 椂層状構造の発達した像から明 らかに ACTH の影響を示するのと理解されるが, 臨床 的にこの症例が dexamethazone suppression test に反応 を示したことを考光合わせると非常に興味深い結果であ る.一方過形成組織について考察してみると Cushing 症 候群の過形成組織で, ACTH 非添加により变性, 壊死を 示し, ACTH 0.2 IU $/ \mathrm{ml}$ 添加により mitochondria, SER. などの基本構造が良好に保存されたことは，生体外にお いてもまた，過形成状態の維持にはACTHを必要と することを示した点で興味あると考えられる. 原発性ア ルドステロン症の過形成組織では ACTH 添加により mitochondria が縮少し free ribosome が増加したが，こ のことは原発性アルドステロン症の過形成が ACTH 以 外の因子で扔こつていると推定してよいかも知れない，

原発性アルドステロン症を呈した腫瘍およびその隣接 副婜皮質組織, Cushing 症候群過形成組織忬よび副腎性 器症候群腺腫組織において myelin 様の特異な膜樣構造 がみられたが，原発性アルドステロン症の本構造につい ては Janigan ${ }^{74)}$ (1963）が spironolactone 投与を受惊た 副腎の Z. glomeruiosa $飞$ laminated acidophilic inclusion を認めて以来, 高安 ${ }^{75)}$ (1967) Jenis and Hertzog ${ }^{76)}$ (1969) 狩野 (1970) Davis and Medline ${ }^{77)}$ (1970) らが電子顕 微鏡的に観察し, spironolactone body (SB) といら名称 が普及してきている，その由来についてはJenis と Davis はSERを強調しているが Fisher and Horvat ${ }^{78)}$ (1971) はラットに spironolactone を投与して電子顕微鏡的観察 を行ないSB は mitochondria の変化したものであると した、本研究に打いては spironolactone の投与を受けた 3 例の原発性アルドステロン症患者の腺腫組織, 全例に おいて中心が明るい同心円ないし層状を呈する表面平滑 
な構造を認め, 一部は vesicle の中に入りこみ周辺には mitochondria が散在していた. さらにこの構造は培養に よりやや数が減るが，あたかも vesicle の中に移動して いくような動的所見を呈した.さらに本研究での新知見 として興味深いことはこれらと類似の構造が Cushing 症 候群の過形成細胞之, 副腎性器症候群の腺腫細胞にもみ られたことである.これらの 3 つのものが従来いわれて いた，いわゆる SB と同一のものか否かについては不明 であるが, 器官培養後の観察でこれら構造に形態的変化 がみられることは確かである.中には移行像の動的瞬間 を捉光た写真子得られ, とくに副腎性器症候群腺腫組織 ではSER ないし RER をとりかこんでいるのが認めら れ, この構造と SER, RER の機能的関係が示された. し かしながら ACTH がこれらに直接影響を与えている という証明はなく, cyclic AMP などを介した間接的作 用を考㝋なければならない、Mitochondria, ER, vesicles （或いは Lipid granules も）3者（或いは4者）は myelin 様層状構造を仲介にして物質の生合成, 移動, 蓄箖を行 なつていることが推定された。

\section{結 語}

ラットの実験的副堅過形成組織およひ16例の臨床例 (対照 5 例, Cushing 症候群の腺腫 3 例, 同過形成 2 例, 原発性アルドステロン症の腺腫 3 例, 同過形成 2 例, 副 腎性器症候群の腺腫 1 例）から得られた材料を器官培養 し次のような結果を得た。

1. 雌性ラットに aniline を投与し, 無処置群と比較 し，明らかな副腎皮質の過形成を認めた。（aniline 1 週 間投与群副腎重量 $260.0 \pm 10.9 \mathrm{mg}$ : 刘照無処置郡 $57.0 \pm$ $6.0 \mathrm{mg})$.

2. 過形成をおこした組織を器官培覣し, ACTHを添 加し, その効果を非添加群と病理組織学的に比較検討し た. その結果，7 日間培養後のラット過形成副㹂皮質組 織の形態保存は, aniline 無処置正常副腎組織に比較し 良好であつた。ささらに $\mathrm{ACTH} 0.2 \mathrm{IU} / \mathrm{ml}$ 添加, 7 日間 培養でのラット副腎皮質過形成状態は, 形態的にもつと も良好に維持された.

3. ヒト正常副腎皮質組織 5 例と11例の副腎皮質機能 古進状態の組織は48時間から7 日間（1部14日間）器官 培養が可能であり，光学顕微鏡および電子顕微鏡的観察 が可能であつた。

4. ヒト正常副腎皮質組織の器官培養では，7日間 まで培着前の各小器官の基本的構造はよく保存され， ACTH $0.02 \mathrm{IU} / \mathrm{ml}$ 添加により, mitochondria の増大,
SER の増加, lipid granules の減少, vesicles の増加が みられた。

5. Cushing 症候群腺腫組織の器官培養では, 7 日間 培養で $\mathrm{ACTH}$ 添加, 非添加群ともに垬本構造をよく保 つたが，14日間培盖では ACTH 非添加群， $0.2 \mathrm{IU} / \mathrm{ml}$ 添加群ともに变性傾向あり, $0.02 \mathrm{IU} / \mathrm{ml}$ 添加で良好に 維持された.

6. Cushing 症候群過形成組織の器官培養では, ACTH の添加により基本構造はよく保存され，ACTH $0.2 \mathrm{IU} /$ $\mathrm{ml}$ の濃度で，より顕著な mitochondria と SER の増大 がみられた。

7. 原発性アルドステロン症腺腫組織の器官培養で は，非腫瘍部分にもみられた myelin 様構造が腫瘍にも みられ，vesicle との間に移行がみられた。 ACTH 添加 では mitochondria がやや大きくなり, vesicle も増し た。

8. 原発性アルドステロン症過形成組織の器官培養で はACTH 添加により mitochondria は小さく線状とな り cristae は消失し lipid granule は減少し, 原発性了 ルドステロン症の過形成は ACTH 以外の因子であるこ との可能性を示した。

9. 副腎性器症候群腺腫組織の器官培養では, 培養前 の構造がよく保たれ，ACTH 0.02 および $0.2 \mathrm{IU} / \mathrm{ml}$ 添 加により mitochondria は増大, lipid granules も増し ER は発達良好であつた。

10. Spironolactone を投与された原発性アルドステロ ン症腺腫組織にみられるといわれる myelin 様構造類似 の層状構造が，Cushing 佂候群過形成組織拉よび副腎性 器症候群腺腫組織に打いても認められた。

11. これらの myelin 様構造は ACTH の添加, 非添 加にかかわらず，培養後特異の層状の形態が流動的変化 を示し，とくに副腎性器症候群腺腫組織飞打いては， SER, RER と密接な関係が観察されたことは，この構造 のもつ機能の一端を示すものとして注目された.

以上, 器官培養法により副腎皮質機能九進状態の組織 を種々な条件下で in vitro に維持せしめ, 機能との関連 性の立場から，その形態を観察することができた．この 方法をさらに発展させることにより，本症の病態生理 に新たな知見を加えることが可能であり，臨床的にも本 注:の診断治療に寄与しうると思われる.

本論文の一部は第60回日本泌尿器科学会総会「副腎病 理カンファレンス」, 拉よび, 67th Annual Meeting of American Urological Association において発表した。 
稿を終るにあたり，御指導，御校閲いただいた大越正 秋教授, 終始直接御指導下さつた田崎宽助教授に心上り 感謝の意を表します。また，御協力戴いた尾関全彦，馬 場志郎両先生に感謝します。さらに臨床例の研究材料の 一部を御提供下さつた，国立東京第二病院，立川共済病 院，静岡赤十字病院，東京電力病院の各泌尿器科に厚く お礼申しあげます。

なお, 本研究の一部は, 文部省科学研究費によつて行 なわれた。

\section{文献}

1) Symington, T.: Brit. J. Urol., 35, 329, 1963.

2) Propst, A.: Beitr. Path. Anat., 131, 1, 1965.

3) Holzmann, K. and Lange, R.: Z. Zellforsch., 69, 80, 1966.

4) Luse, S.: The Human Adrenal Cortex, p. 1. Little, Brown and Company, Boston, 1967.

5) Cervos-Navarro, J., Bayer, M.J., Calvo, R. and Tonutti, E.: Endokrinologie, 51, 289, 1967.

6) Reidbord, H. and Fisher, E.R.: Arch. Path., 86, 419, 1968.

7) Reidbord, H. and Fisher E.,R.: Arch. Path., 88, 155, 1969.

8) Mackay, M.: Functional Pathology of the Human Adrenal Gland p. 345. E and S Livingston Ltd., Edinbrugh and London, 1969.

9) Magadam, R.F.: Cancer 26, 1300, 1970.

10) Sommers, S.C. and Terzakis, J.A.: A.J.C.P. 54, 303, 1970.

11) 中村 章, 田中義憲, 桜井叢人: 日泌尿会誌, 57, 1226, 1966.

12）土山秀雄: 最新医学, 22, 2433, 1967.

13）馬場正郎，畠山 茂：電子顕微鏡による細胞病 理学图譜, p 359,岩波書店, 1967.

14）高安久雄：日泌尿会誌，58，899，1967.

15) Yoshimura, F., Harumiya, K., Watanabe, M., Omoto, T. and Sekiguchi, T.: Endocrinol. Japon., 15, 145, 1968.

16) 狩野健一：日泌尿会誌，61，955，1970.

17) Kovacs, K. Yeghiayan, E. Hatakeyama, S. Selye, H.: Experientia 26, 1014, 1970.

18) Tazaki, H., Ozeki, T., Matsunaga, J., Yajima, T., Ohkoshi, M.: Keio. J. Med., 17, 263, 1968.

19）尾関全彦：日泌尿会誌，59，425，1968.

20) Carrel, A. and Burrows, M.T.: J. Amer. med. Ass., 55, 1379, 1910.

21) Bulliard, H.: Arch. Zool. exp. gen. 61, 533, 1923.

22) Ssipowsky, P.W.: Arch. exp. Zellforsch., 8, 237, 1929.
23) Kasahara, S.: Trans. Soc. path. Jap. Acta, 23, 450, 1933.

24) Lux, L., Higgins, G.M. and Mann, F.C.: Mayo Clin., 10, 461, 1935.

25) Knoll, E.J.: Arch. exp. Zellforsch., 20, 198, 1937.

26) Baker, L.E. and Carrel, A.: J. exp. Med., 70, 29, 1939.

27) Martinovitch, P.N.: Meth. med. Res., 4, 237, 1951.

28) Martinovitch, P.N.: Exp. Cell Res., 4, 490, 1953.

29) Martinovitch, P.N.: J. exp. Zool., 129, 99, 1955.

30) Schaberg, A.: Transplant. Bull., 2, 145, 1955.

31) Schaberg, A.: Anat. Rec., 122, 205, 1955.

32) Schaberg, A.: Nat. Cancer Inst. Monogr., 11, 127, 1963.

33) Shaberg, A. and De Groot, C.A.: Exp. Cell Res., 15, 475, 1958.

34) Schaberg, A. and De Groot, C.A.: Arch. int. Pharmacodyn., 146, 207, 1963.

35) Schaberg, A., De Groot, C.A. and Gjelpke, A.S.: Acta physiol. pharmacol. neerl., 8, 447, 1959 .

36) Trowell, O.A.: $\quad$ Exp. Cell Res., 16, 118, 1959.

37) Kendall. P.A., Meltzed, M.R. and Zimmerman, G.R.: Proc. nat. Acad. Sci., (Wash.) 66, 413, 1959.

38) Kendall, P.A., Zimmerman, G.R. and Folk, G.E. Jr.: Exp. Cell. Res., 21, 274, 1960.

39) Macdougall, J.D.B. and Coupland, R.E.: Exper. Cell Res., 45, 385, 1967.

40) Kahri, A.I., Acta Ecdocr (Kobenhaven), Suppl. 108, 52, 1966.

41) Buonassissi, V., Sato, G. and Cohen, A.I.: Proc. Nat. Acad. Sci. USA, 48, 1184, 1962.

42) Furth, J.: Recent Progress in Hormone Research, vol. 2. p. 22, Academic Press, New Yor,, 1955.

43) Cohen, A.I., Furth, J. and Buffet, R.F.: Am. J. Path., 23, 631, 1957.

44) Cohen, A.I., Bloch, E. and Celozzi, E.: Proc. Soc. Exp. Biol. Med., 95, 304, 1957.

45) Cohen, A.I. and Furth, J.: Cancer Res., 19, 72, 1959.

46) Bloch, E. and Cohen, A.I.: J. National Cancer Inst., 24, 97, 1960.

47) Stollar, V., Buonassissi, V. and Sto. G.: Exp. cell res 35, 608, 1964.

48) Kowal, J. and Fiedler, R.: Arch Biochem 128, 406, 1968.

49) Neville, A.M., Anderson, J.M., McCormick, 
M.H. and Webb, J.L.: J. Endocr. 41, 547, 1968.

50) Bloch, E., Rommey, S.L., Klein, M., Lippiello, L., Cooper, P. and Goldıng, I.P.: Proc. Soc. Exp. Biol. Med. 119, 449, 1965.

51) Stark, E., Gyevai, A., Szalay, K.: Canad. J. Physio and Pharm., 43, 1, 1965.

52) Milner, A.J. and Villee, D.B.: Endocrinology 87, 596, 1970.

53) Villee,D.B.: Adv. Enzyme Regul., 4, 269, 1966.

54) Jones, T., Groom, M. and Criffiths, K.: Biochem. Biophy. Res. Commu., 38, 355, 1970.

55) Kovacs, K., Blasheck, J.A., Yeghiayan, E. and Gardell, C.: Amer. J. Path., 62, 17, 1971.

56) Prader, A. and Gurtner, H.P.: Helv. Peadıat. Acta, 10, 397, 1955.

57) Camacho, A.M., Kowarskı, A., Migeon, C.J. dn Brough, A.J.: J. Clin. Endocin., 28, 153, 1968.

58) Racela, A. Jr., Azarnoff, D. and Svoboda, D.: Lab. Invest., 21, 52, 1969.

59) Cash, R., Brough, A.J., Cohen, M.N.P. and Satoh, P.S.: J. Clin. Endocr., 27, 1239, 1967.

60) Camacho, A.M., Cash, R., Brough, A.J. and Wilroy, R.S.: JAMA, 202, 20, 1967.

61) Lever, J.D.: Endocrinology, 58, 163, 1956.

63) Schwarz, W., Merker, H.J., Suchowsky, G.: Virchow Arch. Path. Anat., 335, 165, 1962.

64) Soeder, H. and Themann, H.: Beitr Path.
Anat., 138, 189, 1968.

65) Smith, P.E.: Am. J. Anmat.. 45, 205, 1930.

66) Haynes, R.C., Jr. and Berthet, L.: J. Biol. Chem., 225, 115, 1957.

67) Haynes, R.C.: J. Biol. Chem. 233, 1220, 1958.

68) Pastan, I., Roth, J. and Macchia, V.: Proc. Natl. Acad. Sci. U.S. 56, 1802, 1966.

69) Taunton, O.D., Roth, J. and Pastan, I.: Biochem. Biophys. Res. Commun., 29, 1, 1967.

70) Grahame-Smith, D.G., Butcher, R.W., Ney, R.L. and Sutherland, E.W.: J. Biol. Chem., 242, 5535, 1967.

71) Newton, M.A. and Laragh, J.H.: J. Clin. Endocr., 28, 1006, 1968.

72) Slaton, P.E. Jr., Schambleman, M. and Biglieri, E.G.: J. Clin. Endocrinol., 29, 239, 1969.

73) Hainsworth, I.R. and Grant, J.L.: Acta endocr. (Kbh.) Suppl. 155, 178, 1971.

74) Janigan, D.T.: Lancet, 1, 850, 1963.

75) 高安久雄, 横川正夫, 岡田清已：日内分泌会誌, 43, 194, 1967.

76) Jenis, E.H. and Hertzog, R.W.: Arch. Path., 88, 530, 1969.

77) Davis, D.A. and Medline, N.M.: Amer. J. Clin. Path., 54, 22, 1970.

78) Fisher, E.R. and Horvat, B.: Arch. Path., 91, 471, 1971.

（1973年 3 月18日受付） 